\title{
Akademik ve Dil Becerileri Eğitim Programının 61-66 Aylık Çocukların Bilişsel Yetenekleri ile Erken Akademik ve Dil Becerilerine Etkisi
}

\author{
The Effect of the Academic and Language Skills Education Program upon 61-66 \\ Month Old Children's Cognitive Skills Early Academic and Language Skills
}

\section{Özgün UYANIK* Fatma ALİSINANOĞLU* ${ }^{* *}$}

\begin{abstract}
$\ddot{O}_{z:}$ Akademik ve dil becerileri eğitim programının 61-66 aylık çocukların bilişsel yeteneklerine ve erken akademik ve dil becerilerine etkisinin incelenmesi amacıyla yapılan araştırmanın örneklemini 61-66 aylık 64 (deney 32, kontrol 32) çocuk oluşturmaktadır. Karma desenli yöntem uygulanan araştırmada, deney grubundaki çocuklara erken akademik ve dil becerileri eğitim programı uygulanmıştır. Araştırmada nicel veriler için Bilişsel Yetenekler Testi Form-6 (BYTF-6)", ve "Kaufman Erken Akademik ve Dil Becerileri Araştırma Testi (K-EADBAT)" nitel verileri değerlendirmek için ise "Akademik ve Dil Becerileri Eğitim Programını Değerlendirme Formu" kullanılmıştır. Deney ve kontrol gruplarından elde edilen nicel veriler tek faktörlü kovaryans analizi ANCOVA ve tek faktör üzerinde tekrarlı ölçümler için iki faktörlü ANOVA ile analiz edilmiştir. Nicel veriler ise betimsel değerler olarak ve Pearson Korelasyon Katsayısı ile hesaplanmıştır. Araştırma sonucunda bilişsel yetenekleri ile erken akademik ve dil becerileri kazanımlarında deney grubu lehine istatistiksel olarak anlamlı geniş etki düzeyinde bir farkın olduğu görülmektedir. Ayrıca her bir etkinliğin eğitimci A ve B tarafından programın özelliklerine uygun olarak uygulandığı ve puanlayıcı güvenirliği korelasyon değerlerinin yüksek olduğu belirlenmiştir.
\end{abstract}

Anahtar sözcükler: Bilişsel Yetenekler, Erken Akademik ve Dil Becerileri, BYTF-6 ve K-EADBAT

Abstract: The aim of this study was to investigate the effect of the academic and language skills educational program on the cognative ability of 61-66 month old children and on their early academic and language skills. The sample contained 64 pre-school children. 32 children of this group were given the Academic and Language Skills Educational program. This study employed the Cognitive Abilities Test Form-6 (CAT-6), the Kaufman Survey of Early Academic and Language Skills (K-SEALS) and the Evaluation Form for Academic and Language Skills Educational Program. As a result of this investigation, the group of ghildren given the Academic and Language Skills Educational program were found to have scored significantly higher, with a large effect upon their cognitive abilities and early academic and language skills. On the other hand, concerning reliability issues, it was found that both teacher A and teacher B implemented the program thoroughly and the inter-rater reliability correlation values were high, concerning the administration of the Academic and Language Skills Educational Program.

Keywords: Cognitive Skills, Early Academic and Language Skills, CAT-6, K-SEALS

\footnotetext{
*Yrd. Doç. Dr., Afyon Kocatepe Üniversitesi, Eğitim Fakültesi, Temel Eğitim Bölümü, Afyonkarahisar. ozgunuyanik@hotmail.com

** Prof. Dr., İstanbul Aydın Üniversitesi, Eğitim Fakültesi, Temel Eğitim Bölümü, İstanbul. alisinanf@gmail.com. Bu çalışma Prof. Dr. Fatma Alisinanoğlu danışmanlığında yürütülen Özgün Uyanik'ın “Akademik ve Dil Becerileri Ĕ̈itim Programının 61-66 Aylık Çocukların Bilişsel Yetenekleri ile Erken Akademik ve Dil Becerilerine Etkisi” isimli doktora tezinden yararlanılarak hazırlanmıştır.
} 


\section{Giriş}

"Bilmek" anlamına gelen Latince bir sözcükten ortaya çıkan bilişsel yetenekler, düşünme ve bilme de yer alan tüm psikolojik işlemleri ve etkinlikleri içermektedir. Bilişsel yeteneğin öğeleri olan zekâ, dikkat, alg1, bellek, problem çözme ve muhakeme becerileri; bireyler tarafindan bilginin edinilmesi, geliştirilmesi, organize edilmesi, karmaşık ve daha yüksek yapıda örgütlemesi gibi tüm psikolojik gelişme süreçlerinin oluşmasını sağlamaktadır (Oakley 2004; Cohen 2013). Öğrenme açısından ön plana çıkan zeka ve dikkat, öğrenme sürecini başlatmakta ve dikkat süresi arttıkça zihinsel yetenekler daha verimli çalışmaktadır. Algı, duyu organlarından elde edilen bilgiyi değerlendirerek çevredekileri anlamlandırmayı, kavramayı ve bilginin daha yüksek seviyede bilişsel süreçlerde işlenmesini; problem çözme ise çocukların neden sonuç ilişkisini kavramasını, sonuçları tahmin etme ve çok yönlü düşünme gibi becerilerini geliştirmektedir (Groome et al. 2005; Kail 2010). Çocukların kazandığı deneyimler ve öğrendikleri bellekte depolanmakta (Groome et al. 2005) ve çocuklar bilişsel süreçlerini kullanarak öğrendiklerini muhakeme etmektedirler (Lee, Anzures \& Freire 2011).

Çocuktaki merak ve keşfetme isteği ile bilişsel yeteneklerin gelişiminin birleşmesi sonucunda, çocuğun dil ve erken akademik becerilerinin gelişimi de ön plana çıkmaktadır. Okul öncesi dönemde dil gelişimi kapsamında dinleme ve okuma anlamaya yönelik "alıcı dil becerilerini"; konuşma ve yazma ise anlatmaya yönelik "ifade edici dil becerilerini" oluşturmaktadır. Aynı zamanda dil becerileri çocukların sözlü dili anlama, kendini sözcüklerle ifade etme ve sözlü ya da yazılı olmayan sosyal iletişim ve pratiklerini anlama becerilerini de içermektedir (Heffelfinger \& Mrakotsky 2006; Kandır et al. 2012). Çocuklar duygu ve düşüncelerini konuşma ve yazma becerilerini kullanarak ifade etmektedir. Okuma ve dinleme becerileri ise konuşma ve yazma becerisi ile iç içe geçmiş ve birbirini destekleyen beceri alanları olarak ortaya çıkmaktadır. Okul öncesi dönemde yer alan okuma-yazma becerileri (sözel dil becerisi ve telaffuz, alfabe bilgisi, fonolojik farkındalık, yazı farkındalığı, yazı öncesi çalışmalar gibi) (Neuman \& Dickinson 2002; Morrow \& Gambrell 2004) ve matematik becerileri (matematiksel kavramlar, tanıma, adlandırma, eşleştirme, karşılaştırma, gruplama, sıralama, sayılar, işlemler, model alma, geometri, uzaysal mantık,ölçme ve grafik oluşturma gibi) erken akademik beceriler olarak adlandırilmaktadır (Ezell \& Justice 2005; Charlesworth \& Lind 2007).

Okul öncesi dönemde çocukların bilişsel yeteneklerinin ve bilişsel gelişiminin normal düzeyde olması erken akademik ve dil becerilerinin de normal gelişim göstermesi için temel niteliktir (Heffelfinger \& Mrakotsky 2006). Bu bağlamda eğitim süreçlerinin planlanmasında ilk göz önüne alınan nokta, bireylerin bilişsel yapılarının ve akademik içeriğin sıkı bir şekilde bütünleştirilmesidir. Dil ve akademik becerilerin geliştirilmesi eğitim ve öğretim sürecinin en önemli etkinlikleri arasında yer alırken bilişsel gelişimin de kalbini oluşturmaktadır (Bidell \& Fischer 2005). Çocuklar dil, okuma yazma ve matematik ile ilgili öğrenme yaşantılarında bu alanlarla ilgili becerilerini geliştirirken; kendi bilişsel yapılarını ve yeteneklerini de oluşturmakta ve kullanmaktadırlar (Cohen 2013). Berninger ve Richards (2002), Swanson ve Berninger (1996) bellek bileşenleri ile akademik beceriler arasında güçlü ilişkilerin olduğunu ortaya koymuşlardır. Engle (1996) çalışan belleğin kapasitesi ile dil, okuma, konuşma, sözel yönergeleri takip etme, sözcük bilgisi, not alma, yazma, muhakeme ve kompleks öğrenme becerileri arasında yüksek bir ilişkinin olduğunu belirlemiştir (Akt. Dehn 2008, 93).

Dilin işlevselliğini savunan araştırmacılar dil gelişimi ile bilişsel süreçler arasında bir ilişkinin olduğunu savunmakta; konuşma, anlama ve düşünmenin birbiriyle yakından ilişki içerisinde olduğunu vurgulamaktadırlar (Nadal, Amengual-Bunyola, Ramis, Capo \& CelaConde 2006). Dil gelişimi, beynin gelişimsel aşamalardan geçtiği bir döneme denk gelmektedir. 
Konuşma dilini edinmek, beyin hücreleri arasında sinaptik bağlantıların oluşmasını sağlamaktadır. Bu bağlantıların oluşması ise çocukların bilişsel şemalarını zenginleştirerek dili kullanma (konuşma), dili anlama becerilerinin gelişmesini etkilemektedir. Ayrıca, konuşma dilini anlama işlevi; kısa süreli belleğin yardımı olmadan dışarıdan gelen bilgilerin direk uzun süreli bellekte bulunan kavram ve bilgiler ile ilişkilendirilerek gerçekleşmesi ile de ortaya çıkmaktadır. Çalışan belleğin kapasitesi sözcük öğrenme sürecini etkileyen en önemli noktalardan biri olarak da kabul edilmektedir. Bu nedenle dil, bilişsel becerilerin gelişiminde önemli bir role sahiptir (Topbaş 2005).

Dil gelişimine paralel olarak okuma ve yazma becerilerinin gelişimi de gerçekleşmektedir. Okul öncesi dönemde dil gelişimine ilişkin yapılan bütün çalışmalar ve etkinlikler, ileriye dönük okuma yazma becerilerinin gelişiminde de etkili olmaktadır (Burgess 2002; Furness \& Samuelsson 2009). Diğer yandan okul öncesi dönemde çocukların alg1 ve dikkat gelişimleri ile eşleştirme, ilişki kurma, sıralama, gruplama, problem çözme, muhakeme gibi bilişsel yeteneklerin gelişimi okuma ve yazma becerilerinin gelişiminde önemli rol oynamaktadır (Klauer \& Phye 2008). Poe, Burchinal ve Roberts (2004) çocukların evde ve okulda aldıkları dil becerileriyle ilgili eğitimlerin, onların okuma, fonolojik farkındalık ve okuma becerileri kazanımlarına etkisi olduğunu göstermektedir. Smith-Spark ve Fisk (2007) ve Swanson ve Jerman (2007) çalışan bellek ile okuma becerisi arasında güçlü ilişkiler olduğunu tespit etmişlerdir (Akt. Dehn 2008, 100). Yazzie (2009) yaşları sekiz ile on iki arasında değişen çocuklarda görsel-uzamsal muhakeme yeteneği ile akademik başarı arasında pozitif yönde kuvvetli bir ilişki saptamıştır. Çocukların bilişsel yetenekleri ile ilişki içerisinde olan ve akademik beceri alanı içerisine giren diğer bir alan ise matematik becerileridir. Matematiksel beceriler içinde bulunan sayılar ve işlemler, sınıflama, ayırma, model alma ve ilişkiler, ölçme gibi temel becerilerde başarılı olma üst düzey bilişsel becerilerin çalışmasını gerektirmektedir (Dehn 2008). Çocukların matematiksel problem çözmeleri bilişsel süreçleri kullanması ile de ilişkilidir. Çocuklar matematiksel bir hipotezle karşılaştıklarında, kanıtları geliştirme ve değerlendirmeyi öğrenerek muhakeme yapmaktadırlar. Aynı zamanda matematikle ilgili deneyimleri artıkça ve gelişimle birlikte mantıksal muhakeme yetenekleri de artmaktadır (Churcman 2007). Tomic ve Klauer (1996) tümevarıma dayalı muhakeme eğitim programının çocukların zekâ ve matematik performanslarına; Holmes ve Adams (2006) kısa süreli bellek bileşenlerinin matematik becerilerine etkisi olduğunu tespit etmişlerdir. Van der Sluis, De Jong ve Van der Leij (2007) muhakeme, okuma ve aritmetik arasındaki ilişkilerin yüksek olduğunu; Klein, Adi-Japha ve Hakak Benizri (2010) erkek çocukların matematik başarısı ile görsel-uzamsal muhakeme arasında, kız çocuklarının matematik başarısı ile de sözel muhakeme arasında anlamlı bir ilişkinin olduğunu tespit etmişlerdir.

Okul öncesi dönem çocukları dikkat, algı, bellek, muhakeme, problem çözme becerilerini destekleyici nitelikli ve yaparak yaşayarak öğrenme imkânı sunulan eğitim programlarına dâhil olduklarında, bilişsel yeteneklerini geliştirilebilmekte ve daha üst düzeyde kullanabilmektedirler. Kaymak (1995) beş yaş grubundaki çocuklara uygulanan dikkat eğitimi programının çocukların dikkatlerini toplama yeteneklerini olumlu yönde arttırdığını; Koç (2002) görsel algı becerilerinin gelişimine yönelik program modelinin anasınıfına devam eden çocukların gözmotor koordinasyonu, şekil-zemin algılama, şekil sabitliğini algılama, mekân ile iki konumu algılama ve mekân ilişkilerini algılama boyutlarında anlamlı bir gelişme gösterdiğini; Anlıak (2004) beş-altı yaş grubu çocuklarda kişiler arası bilişsel problem çözme becerileri programı ile zenginleştirilen okul öncesi eğitim programının çocukların problem çözme becerilerini geliştirmelerinde etkili olduğunu; Ünal (2007) anasınıfına devam eden altı yaş grubu çocuklara uygulanan kısa süreli bellek eğitim programının çocukların kısa süreli bellek kapasitelerinin artmasına etki ettiğini saptamıştır. Ayrıca erken akademik ve dil becerileri ile ilgili araştırmalar 
incelediğinde; çocuklar dil, okuma ve yazı farkındalığı ile matematik becerileri yönünden desteklenen zengin eğitim ortamları içerisinde nitelikli okul öncesi eğitim programlarına dâhil olduklarında erken akademik ve dil becerilerinin olumlu yönde gelişim gösterdiği görülmektedir (Campbell, Pungello, Miller-Johnson, Burchinal \& Ramey 2001; Burger 2010). Justice, Chow, Capellini, Flanigan ve Colton (2003) yazma, yazı farkındalığ 1 ve fonolojik farkındalık becerileri desteklenen okul öncesi dönemdeki çocukların okuma ve yazma gelişimlerinin, sadece hikaye okuma etkinlikleri aracılığıyla desteklenen çocuklara göre daha iyi olduğunu; Yayla (2003) dil eğitim programının alt sosyo-ekonomik düzeydeki ailelerden gelen 60-72 aylar arasındaki çocukların dil gelişimini olumlu yönde etkilediğini; Aram ve Biron (2004) yazma programı ile desteklenen okul öncesi dönemdeki çocuklarının okuma ve yazma becerilerinin, okuma programı ile desteklenen çocuklara göre daha fazla ilerleme gösterdiğini; Young-Loveridge (2004) oyunlar ve sayı kitaplarının kullanıldığı bir programın erken çocukluk döneminde çocukların sayı algılamalarını; Sophian (2004) deneysel matematik programının çocukların matematikle ilgili becerilerinin gelişmesinde; Turhan (2004) anasınıfına devam eden alt sosyo-ekonomik düzeydeki çocuklara uygulanan matematiksel kavramları destekleyici eğitim programının çocukların cümle ve sayı olgunluk becerilerini olumlu yönde etkilediğini; Starkey, Klein ve Wakaley (2004) erken matematik kavrama programının çocukların matematiksel bilgi gelişiminde etkili olduğunu tespit etmişlerdir. Alan yazında yapılan bu araştırmalar çocukların bilişsel yeteneklerinin ile erken akademik ve dil becerilerinin okul öncesi dönemde desteklenmesinin gerekliliğini açıkça ortaya koymaktadır. Bununla birlikte, eğitim programlarının çocuklar üzerindeki etkililiğinin artması, programın çocukların gelişimsel özelliklerine uygun bir şekilde hazırlanmasının dışında, eğitimin bileşenlerini oluşturan öğrenme süreci, öğrenme ortamı, öğretmen özellikleri, materyallerin ve değerlendirmenin de programın uygulanması sürecinde etkin olarak gerçekleştirilmesine bağlıdır (Kandır, Özbey \& İnal 2010). Öğrenme ortamının sıcak ve olumlu olması, ortamın öğrenme kazanımlarına uygun bir şekilde düzenlenmesi, güvenliği, öğrenme sürecinde çocukların dikkatlerinin çekilmesi, etkinliklerle ilgili uygun, anlaşılır yönergeler verilmesi, etkinliklerin kazanım ve göstergelerle ilişkilendirilerek uygulanması, etkinliklerin içerisinde yer alan yöntem, strateji ve tekniklerin özelliklerine uygun uygulanması, öğretmenin beden dili ve ses tonunu kullanabilmesi ve çocuklarla birlikte hareket edebilmesi, zamanı ve materyalleri etkili kullanması ve etkinlik sonunda değerlendirme yapması gibi özellikler hazırlanan eğitim programlarının çocuklar üzerinde daha etkili olmasını sağlamaktadır (Kandir et al. 2010; Beaty 2014).

Araştırma sonuçlarından da anlaşılacağı gibi Türkiye'de çocukların bilişsel yetenekleri ile erken akademik ve dil becerileri konusunda yapılmış ayrı çalışmalar olmasına rağmen, bunları bütünlük içinde alan ve özellikle okul öncesi dönemdeki çocukların bilişsel yetenekleri ile erken akademik ve dil becerilerini bir bütün içerisinde destekleyen eğitim programına ve bu programın etkisini inceleyen çalışmalara rastlanılmamaktadır. Bilişsel yetenekler ile dil ve akademik becerilerin birbiri ile iç içe geçmiş ayrılamayan ve birlikte gelişim gösteren iki alan olduğu göz önüne alındığında; erken akademik ve dil becerilerinin desteklenmesi amacıyla eğitim programının geliştirilmesi ve eğitim sonucunda çocukların sözel ve sayısal bilişsel yetenekleri ile erken akademik ve dil becerilerinin üst düzeye çıkarılmasının önemli olduğu görülmektedir. Ayrıca eğitim programının 61-66 aylık çocukların devam ettiği okul öncesi eğitim kurumlarında görevli öğretmenlere farklı bir bakış açısı kazandırmakta yararlı olacağ1 ve bilişsel yetenekler ile erken akademik ve dil becerileri konularında yapılan çalışmalara temel oluşturacağı, yeni bir bakış açısı sağlayacağı ve katkı sağlayacağı düşünülmektedir. Bu noktadan hareketle araştırmanın temel amacını; akademik ve dil becerileri eğitim programının 61-66 aylık çocukların bilişsel yetenekleri ile erken akademik ve dil becerilerine etkisinin incelenmesi oluşturmaktadır. 
$\mathrm{Bu}$ temel amaç doğrultusunda aşağıdaki sorulara yanıt aranmıştır.

1. Deney ve kontrol grubunda bulunan çocukların BYTF-6 Toplam ön test puanlarına göre düzeltilmiş son test puanları arasında manidar bir fark var mıdır?

2. Deney ve kontrol grubunda bulunan çocukların K-EADBAT Toplam ön test puanlarına göre düzeltilmiş son test puanları arasında manidar bir fark var mıdır?

3. Deney grubunda bulunan çocukların BYTF-6 Toplam ön test, son test ve kalıcılık testi puanları arasında manidar bir fark var midır?

4. Deney grubunda bulunan çocukların K-EADBAT Toplam ön test, son test ve kalıcılık testi puanları arasinda manidar bir fark var midir?

5. Araştırmaya katılan öğretmenler, akademik ve dil becerileri eğitim programını, akademik ve dil becerileri eğitim programı değerlendirme formu'nda belirtilen özelliklere göre nasıl uygulamışlardır?

\section{Yöntem}

\section{Araştırmanın Modeli}

Araştırmada karma desenli yöntem uygulanmıştır. Karma desenli yöntem, bir araştırma deseninin güçlendirilmesinde kullanılan temel yollardan biridir. Araştırmada tek bir yöntem yerine birbirini destekleyen, entegre olan iki ya da daha fazla yöntemin birlikte kullanılmasını ve böylece yöntemde zenginleşmeyi sağlamayı amaçlayan bir uygulamadır. Ayrıca karma desenli yöntem, araştırmacının bir yöntem kullanarak elde edebileceği bakış açısını genişleterek ona farklı bakış açılarından bakma firsatı sunmakta ve tekli metot kullanımlarında karşılaşılan sınırlılıkları en aza indirmeye çalışmaktadır. Böylece araştırmacının elde ettiği sonuçların güvenirliğini artırmakta, teori ve bilgi gelişimine katkılarda bulunmaktadır (Cresswell \& Plano-Clark 2007; Balc1 2011). Bu nedenle araştırma deneysel nitelik özelliği taşıdığından; ön-test/son-test, deney-kontrol gruplu deneysel desen ve nitel araştırma türlerinden doğrudan gözlem ve görüntü analizi yöntemi kullanılmıştır. Deneysel araştırmalar, araştırmacı tarafından oluşturulan farkların bağımlı değişken üzerindeki etkisini test etmeye yönelik çalışmalardır. Deneysel desenlerde temel amaç değişkenler arasında oluşturulan neden-sonuç ilişkisini test etmektir (Büyüköztürk, Kılıç-Çakmak, Akgün, Karadeniz \& Demirel 2012). Araştırmadaki deneysel desende bağımlı değişken; okul öncesi eğitim kurumuna devam eden 61-66 aylar arasında yer alan çocukların "Bilişsel Yetenekleri ile Erken Akademik ve Dil Becerileri", çocukların Bilişsel Yetenekleri ve Erken Akademik ve Dil Becerileri üzerine etkisi incelenen bağımsız değişken ise; "Akademik ve Dil Becerileri Eğitim Programı"dır. Araştırmada test gibi nicel araçların yanı sıra araştırmayı zenginleştirmek, araştırma problemine ve olguya birden fazla data kaynağından bakma olanağı yakalamak, yöntemsel ve bireysel yanılgıları en aza indirerek araştırmanın genellenebilirliğini en üst düzeye çıkarmak amacıyla nitel araştırma türlerinden doğrudan gözlem yönteminden katılımcı gözlem ve dökümanların incelenmesi (görüntü analizi) yöntemlerinden de yararlanılmış ve bu desende araştırmacı tarafından nicel ve nitel veriler eş zamanlı toplanmıştır (Cresswell \& Plano-Clark 2007; Büyüköztürk et al. 2012). Doğrudan gözlem; hem nitel hem de nicel araştırma tekniklerinde kullanılan, olguların araştırmacı tarafindan oldukça yansız olarak olduğu gibi gözlenip kayıt edilmesini kapsamaktadır (Sönmez \& Alacapınar 2013).Görüntü analizi, temel veri toplama aracı olabileceği gibi gözlem, görüşme veya doküman incelemesi gibi veri toplama yöntemleri ile birlikte ek veri kaynakları olarak kullanılmakta ve nitel araştırmanın güvenirliğini önemli ölçüde arttırmaktadır (Yıldırım \& Şimşek 2005). Daha sonra bu bulgular kullanılarak verilerin birbirini destekleyip desteklemediği incelenmiştir. 


\section{Evren ve Örneklem}

Araştırmanın evrenini 2012-2013 eğitim yılında Ankara il merkezi Çankaya ilçesinde bulunan Milli Eğitim Bakanlığı'na bağlı anasınıflarına devam eden 61-66 aylık çocuklar oluşturmaktadır. Örnekleme ise evren içerisinden daha önce akademik ve dil becerileri ile bilişsel yeteneklerini destekleyici özel bir eğitim programı kapsamına alınmamış, araştırmaya katılmaya gönüllü, normal gelişim gösteren ve sosyo demografik özellikleri benzer olan anasınıfı çocukları arasından tesadüfî olarak seçilen 32 deney, 32 kontrol grubu olmak üzere toplam 64 çocuk alınmıştır. Araştırmada yansız atama kullanılmadan, hazır gruplardan ikisi bilişsel yetenekler ve erken akademik becerileri açısından eşleştirildiğinden ve bilişsel yetenekler ve erken akademik becerileri açısından eşit olan gruplar seçkisiz olarak deney ve kontrol grubu olarak belirlendiğinden yarı deneysel desen kullanılmıştır (Büyüköztürk et al. 2012).

Deney grubundaki çocukların, \%53,1'nin erkek, \%46,9'nun kız; \%46,8'nin iki kardeş, $\% 43,8$ 'nin tek çocuk ve $\% 9,4$ 'nün üç ve daha fazla kardeşe sahip olduğu; $\% 50,0$ 'sinin daha önce okul öncesi eğitim aldığı, \%50,0'sinin daha önce okul öncesi eğitim almadığı belirlenmiştir. Ayrıca; çocuklarının annelerinin \%81,3'nün 30-39 yaş arası, \%15,6'sının 29 yaş ve altı, \%3,1'nin 40 yaş ve üzeri olduğu; babalarının ise, $\% 84,4$ 'nün 30-39 yaş ve aras1, $\% 9,4$ 'nün 40 yaş ve üzeri, $\% 6,2$ 'sinin 29 yaş ve altı olduğu görülmektedir. Annelerinin, \%53,1'nin lise, \%25,0'nin ilköğretim, \%21,9'nun üniversite mezunu; babalarının \%43,8'nin lise, \%31,2'sinin üniversite, \%25,0'nin ilköğretim mezunu olduğu belirlenmiştir. Annelerinin mesleğine göre dağılımları incelendiğinde, \%53,1'nin çalışmadığ1, \%21,9'nun serbest meslek yaptığı \%12,5'nin memur, $\% 12,5$ 'nin işçi; babalarının ise, \%50,0'sinin serbest meslek, \%31,2'sinin işçi, \%18,8'nin memur olduğu görülmektedir. Kontrol grubundaki çocukların, \%56,3'nün erkek,\%43,7'sinin kız; $\% 62,5$ 'nin iki kardeş, \%28,1'nin tek çocuk, \%9,4'nün üç ve daha fazla kardeşe sahip olduğu, $\% 46,9$ 'nun daha önce okul öncesi eğitim aldığ1, \%53,1'nin daha önce okul öncesi eğitim almadığı belirlenmiştir. Ayrıca, \%65,6'sının 30-39 yaş ve arası, \%21,9'nun 40 yaş ve üzeri olduğu, \%12,5'nin 29 yaş ve altı; babalarının ise \%50'sinin 30-39 yaş ve arası, \%46,9'nun ise 40 yaş ve üzeri, \%3,1'nin 29 yaş ve altı olduğu görülmektedir. Annelerinin, \%53,1'nin lise, \%31,3'nün üniversite mezunu, \%15,6'sının ilköğretim mezunu olduğu; babalarının ise, \%43,8'nin üniversite, \%34,3'nün lise, \%21,9'nun ilköğretim mezunu olduğu görülmektedir.

Deney ve kontrol gruplarının belirlenen değişkenler açısından denk olup olmadıklarını belirlemek amacıyla eğitim programı uygulanmaya başlanmadan önce araştırmacı tarafindan BYTF-6 ile K-EADBAT uygulanmıştır. Uygulanan ön test sonuçları esas alınarak, ortalamalar arası fark bağımsız gruplarda t-testi kullanılarak test edilmiştir. $t$ testine ilişkin sonuçlar Tablo 1'de verilmiştir.

Tablo 1. Deney ve Kontrol Gruplarının BYTF-6 Toplam ve K-EADBAT Toplam Ön Test Puanlarına Göre - Bağımsız Gruplarda t-Testi Sonuçları

\begin{tabular}{|c|c|c|c|r|r|r|r|}
\hline Grup & Testler & $\mathbf{n}$ & $\overline{\boldsymbol{X}}$ & Ss & sd & t & p \\
\hline Deney & BYTF-6 Toplam & 32 & 52,63 & 11,505 & 62 &,- 776 & \multirow{2}{*}{, 441} \\
\hline Kontrol & BYTF-6 Toplam & 32 & 54,63 & 8,961 & 62 & & \\
\hline Deney & K-EADBAT Toplam & 32 & 52,41 & 9,193 & 62 & \multirow{2}{*}{,- 168} & \multirow{2}{*}{, 867} \\
\hline Kontrol & K-EADBAT Toplam & 32 & 52,84 & 11,548 & 62 & &
\end{tabular}

Tablo 1 incelendiğinde, deney ve kontrol gruplarının BYTF-6 toplam ve K-EADBAT toplam ön test puanlarına göre yapılan bağımsız gruplarda $t$ testi sonuçlarına göre, deney ve kontrol grubundaki çocukların BYTF-6, toplamına ait ön test puan ortalamaları arasında $(\mathrm{t}=-.776$, $\mathrm{p}>.01)$ ve K-EADBAT toplam puanı ön test puan ortalamaları arasinda $(\mathrm{t}=-.168, \mathrm{p}>.01)$ 
anlamlı bir farklılık olmadığı belirlenmiştir. Bu sonuca göre, eğitime başlarken deney ve kontrol grubundaki çocukların bilişsel yetenekleri ve erken akademik ve dil becerileri yönünden benzer özelliklere sahip olduğu söylenebilir. Kontrollü ön test son test modelli çalışmalarda deney ve kontrol gruplarına ait ön test puanlarının olabildiğince birbirine yakın olması gerekmektedir (Kaptan,1998). Bu durumun, deney grubuna uygulanacak eğitimin etkililiğini ortaya koyması bakımından önemli olduğu ifade edilebilir.

\section{Verilerin Toplanması}

Araştırma, Ankara İl Milli Eğitim Müdürlüğü’nden gerekli izinler alındıktan sonra ailelerle yapılan toplantı sonucunda araştırmaya katılmaya gönüllü olan aileler ve çocukları ile gerçekleştirilmiştir. Araştırmada çocuklar ve ailelerle ilgili kişisel bilgileri (cinsiyet, kardeş sayısı, okul öncesi eğitime devam etme süresi, anne ve babanın yaşları, öğrenim durumu, meslekleri) toplamak amacıyla araştırmacı tarafından geliştirilen "Genel Bilgi Formu" ve Akademik ve Dil Becerileri Eğitim Programı'nın deney grubundaki öğretmenler tarafından uygulanmasını değerlendirmeye yönelik "Akademik ve Dil Becerileri Eğitim Programı Gözlem Kayıt Formu" kullanılmıştır. Bunun yanı sıra çocukların bilişsel yeteneklerini belirlemek amacı ile "Bilişsel Yetenekler Testi Form, 6 BYTF-6 (Cognitive Abilities Test Form 6)" ve çocukların erken akademik ve dil becerilerini değerlendirmek amacıyla "Kaufman Erken Akademik ve Dil Becerileri Araştırma Testi, K-EADBAT (Kaufman Survey of Early Academic and Language Skills)" veri toplama aracı olarak kullanılmıştır.

Akademik ve Dil Becerileri Ĕ̈̆itim Programı Gözlem Kayıt Formu: Eğitim programlarının uygulama sürecinde, hem öğretim biçiminin hem de ele alınan içeriğin denetlenmeye ve kontrole ihtiyacı vardır. Eğitim programlarının uygulanma sürecinde uzmanlar tarafından yap1lan gözlem, örnek öğretim, öğretmen konferansları, personel gelişim toplantıları gibi yöntemler, programı uygulayan öğretmenlere rehberlik ve yönlendirme sağlar ve öğretmenlerin davranış değişimini gerçekleştirmek için gerekli becerilere sahip olduklarının güvencesini verir (Ornstein \& Hunkins 2014). Bir gözlem sürecinde her şeyi gözlemek mümkün olmadığından gözleme başlamadan önce neyin hangi kapsamda gözleneceğinin açı bir biçimde ortaya konması gerekmektedir (Patton 2002). Bu nedenle Akademik ve Dil Becerileri Eğitim Programı Gözlem Kayıt Formu, öğretmenin uygulaması ve Akademik ve Dil Becerileri Eğitim Programı'nın değerlendirilmesine yönelik bilgi almak amacıyla araştırmacı tarafından hazırlanmıştır. Gözlem Formu, eğitim ortamının düzenlenmesi, güvenliği, materyallerin uygun biçimde kullanılması, etkinliklerin aşamalarına ve uygun yönteme göre uygulanması, öğretmenin ses tonunu, beden dilini kullanması, etkinlikle ilgili değerlendirme sorularını sorması ve çocuklara dönütler vermesine yönelik 20 soruyu içermektedir (MEB 2006-2013; Kandır et al. 2010). Form hazırlandıktan sonra kapsam geçerliliğini yapmak amacıyla, toplam üç okul öncesi ve çocuk gelişimi uzmanı, bir eğitim bilimleri uzmanı ve bir ölçme ve değerlendirme alanındaki uzmanlara gönderilerek görüşlerine sunulmuştur. Uzmanlardan gelen görüşler doğrultusunda düzeltmeler yapılarak son şekli verilmiştir. "Akademik ve Dil Becerileri Eğitim Programı Değerlendirme Formu” 20 maddeden oluşmasına rağmen; Programın öğretmen A ve B tarafindan uygulanmasına ilişkin gözlem ve görüntü analizi sonuçlarına göre araştırmacı ve diğer puanlayıcı tarafından doldurulan form sonuçlarında madde sayısının birinci etkinlik dışında diğer etkinlikler için 18-19 arasında alınmıştır. Formda bulunan "Tekerleme, şarkı, parmak oyunu ve öykü gibi etkinlikleri özelliklerine uygun olarak gerçekleştirdi”, "Etkinlikler için belirlenen hedef sözcüklere çocukların dikkatini çekti", "Hedef sözcüklere yönelik çocuklara açılayıcı bilgiler verdi", "Etkinlikte geçen teknolojik materyalleri gerektiği gibi kullandı" maddeleri etkinliklerin tamamına uygun olmadığından bu maddeleri desteklemeyen etkinlikler için değerlendirmeye alınmamıştır. 
Bilişsel Yetenekler Testi Form 6 BYTF-6 (Cognitive Abilities Test Form 6- CATF-6): BYTF-6, Lorge ve Thorndike tarafindan 1954 y1lında geliştirilen 'Zeka Testi (Intelligence Test)'nin son versiyonudur. Test en son olarak 2000 yllında Lohman ve Hagen tarafindan geliştirilmiştir. BYTF-6, 5-18 yaş arasındaki çocukların sözel, sayısal ve sözel olmayan muhakeme ve problem çözebilme becerilerinde eriştikleri düzeyin değerlendirilmesini amaçlamaktadır. Test, benzerlik ve farklılıkları ayırt edebilme, genelden özele sonuç çıkarabilme, problem durumunu anlayabilme ve problem durumunu çözebilme, objeleri sınıflayabilme ve bilgiler arasında transfer yapabilme gibi becerileri değerlendirmektedir. Bireysel ya da küçük grup olarak uygulanabilen BYTF-6 muhakeme yeteneğini sözel "kelimeler ile verilen kavramları ve bilgileri anlamaya ve değerlendirmeye bağlı olarak akıl yürütebilme", sayısal "matematiksel tahminleri oluşturma, matematiksel tartışmaları geliştirme ve değerlendirme, matematiksel bilgileri çeşitli şekilde sunma becerileri" ve "görsel olarak verilen semboller/figürler arasındaki ilişkilere bağh olarak sonuç çıkarabilme" sözel olmayan üç boyutla değerlendirmekte olan 120 sorudan oluşmaktadır. Testin her alt boyutunda 40 adet dört seçenekli çoktan seçmeli soru bulunmaktadır. Tüm boyutlardaki her maddenin çoktan seçmeli cevapları resim olarak gösterilmiştir. Her resmin altında da içi boş daire vardır. BYTF-6'nın uygulaması sırasında her maddedeki soru yüksek sesle okunur ve çocuklardan resmin altındaki dairelerden birini işaretlemeleri istenir. Testi uygulayan kişi çocuğun dairelerden birinin içini işaretlediğinden emin olduktan sonra diğer maddeye geçer. Testin uygulanması 30-40 dakika arasında sürmektedir. Her doğru yanıt için bir (1) puan, her yanlış yanıt için sıfır (0) puan işlenmektedir. İnal (2011), tarafından Afyonkarahisar ili merkez ilçedeki beş ilköğretim okulunun bünyesindeki anasınıflarına devam eden ve normal gelişim gösteren 61-72 aylık 380 çocuk üzerinde yapılan geçerlik güvenirlik çalışmasında, BYTF-6 toplam güvenirlik katsayısının KR$20=.91$ belirlenmiştir. Test tekrar test güvenirliğine göre, BYTF-6'nın toplam için .984 olarak belirlenmiş olup iki test sonuçları arasındaki ilişkinin anlamlı olduğu görülmüştür $(p<0.05)$. Araştırmada, birinci alt problem için, BYTF-6'nın sözel muhakeme (40 madde) ve sayısal muhakeme (40 madde) boyutları ön test-son test ve kalıcılık testi olarak uygulamış bu araştırmada toplam puan üzerinden analizler gerçekleştirilmiştir.

Kaufman Erken Akademik ve Dil Becerileri Araştırma Testi K-EADBAT (Kaufman Survey of Early Academic and Language Skills- K-SEALS): K-EADBAT Alan S. Kaufman ve Nadeen L. Kaufman tarafindan Amerika Rehberlik Servisinde (Amarikan Guidance Service) 1993 yılında geliştirilmiştir. Test, 36-83 ay arasındaki çocukların, erken dil, bilişsel yeterlik ve erken akademik becerilerinin değerlendirilmesini sağlamaktadır (Kaufman \& Kaufman 1993). K-EADBAT, çocukların erken akademik ve dil becerilerini kapsayacak şekilde Sözcük Bilgisi, Sayılar, Harfler \& Sözcükler ve Telaffuz Araştırması olmak üzere üç alt testten, alt testlere bağlı İfade Edici Dil Becerileri, Alıcı Dil Becerileri, Sayı Becerileri ve Harf \& Sözcük Becerileri olmak üzere dört ölçekten ve Erken Akademik \& Dil Becerileri Bileşiğinden oluşmaktadır. Sessiz ve rahat bir ortamda uygulanmaktadır. Test uygulanırken test kitapçığındaki her maddenin resmi çocuklara gösterilerek, resme ait yönerge yüksek sesle okunmakta ve çocuklardan cevap vermeleri beklenmektedir. Her doğru yanıt için test kayıt formuna bir (1) puan, her yanlış yanıt için sıfır (0) puan işlenmektedir. Testin tümü toplam 90 maddeden oluşmakta ve uygulanması her çocuk için 15-25 dakika arasında sürmektedir. Her alt test için ham puan, doğru yanıtlanmış olan madde sayısıdır (Kaufman \& Kaufman 1993).Türkiye'de Uyanık ve Kandır (2014) tarafından Türkçe'ye uyarlanan K-EADBAT toplama ilişkin doğrulayıcı faktör analizi sonuçlarına göre tek boyutlu faktör yapısının doğrulandığı saptanmıştır. K-EADBAT’a ilişkin KR-20 güvenirlik katsayısının .971 ve maddelerin çoğunluğunun madde toplam korelasyon katsayısının yüksek derecede güvenirlik düzeyinde olduğu belirlenmiştir. K-EADBAT toplam için test tekrar test korelasyonu .908 olarak belirlenmiştir. İki test sonuçları arasındaki ilişkinin 
$\mathrm{p}<0.01$ düzeyinde anlamlı olduğu saptanmıştır (Uyanık ve Kandır 2014). Araştırmanın ikinci alt problemi için, K-EADBAT ön test-son test ve kalıcılık testi olarak uygulanmış ve toplam puanı üzerinden analizler gerçekleştirilmiştir.

Akademik ve Dil Becerileri Eğitim Programı:Araştırmacı tarafından geliştirilen "Akademik ve Dil Becerileri Eğitim Programı" okul öncesi dönemde 61-66 aylık çocukların bilişsel yeteneklerini ve erken akademik ve dil becerilerini desteklemeyi esas almaktadır. Akademik ve Dil Becerileri Eğitim Programı'nın geliştirilmesi için ilgili kitaplar (Amsel \& Byrnes 2002; Garton 2004; Riley 2006; Browne 2007; Strickland \& Riley-Ayers 2007; Clements \& Sarama 2009; Reed 2009; Kandır et al. 2010; Cohen 2013) ile Montessori, High Scope, Regio Emilia gibi okul öncesi eğitim yaklaşımlarının program içerikleri ve uygulamaya yönelik çeşitli araştırmalar (Starkey et al. 2004; Murphy 2007; Ünal 2007; Sarıtaş 2010; Welsh, Nix, Blair, Bierman \& Nelson 2010; Şimşek 2011) incelenmiştir. Yapılan incelemeler sonucunda akademik ve dil becerileri ile ilgili alanın oldukça geniş olduğu görülmüştür. Bu nedenle eğitim programı iki aşamalı olarak planlanmıştır. Birinci aşamada alan ile ilgili daha basit eğitim süreçlerine yer verilirken ikinci aşamada ise daha zor eğitim süreçlerine yer verilmesinin gerekli olduğu görülmüştür. $\mathrm{Bu}$ araştırma kapsamında eğitim programının birinci aşamasındaki eğitim süreçlerine yer verileceğinden Akademik ve Dil Becerileri Eğitim Programı'nda öğrenme süreçlerinin yirmi tanesinin "dil ve okuma-yazmaya hazırlık" ve diğer yirmi tanesinin ise "matematik" alanlarından hazırlanmasına karar verilmiştir. Öğrenme süreçlerinin hazırlanmasında ilgili literatür analizleri ile birlikte MEB Okul Öncesi Eğitim Programı'nda (2006) yer alan amaç ve kazanımlar gözden geçirilmiştir. Daha sonra bu amaç ve kazanımlar temel alınarak, çocukların yakın çevresinden uzak çevresine, basitten karmaşığa, somuttan soyuta ilkeleri dikkate alınarak öğrenme süreçleri planlanmıştır. Deney grubuna uygulanacak olan Akademik ve Dil Becerileri Eğitim Programı'nda, yer alacak etkinliklerde yöntem olarak bilişsel yeteneklerine (dikkat, algı, bellek, problem çözme, muhakeme) yer verilerek etkinlikler temel etkinliklerle bütünleştirilmiştir. Program çocukların aktif katılımını sağlayacak şekilde hazırlanmış ve bütünleştirilmiş olarak oyun temelli dil, okuma yazmaya hazırlık ve matematik etkinlikleri yer almaktadır. Dil etkinliklerinde, çocukların yapılacak etkinliğe zihinsel ve psikolojik açıdan hazırlanmasına, duygu ve düşüncelerini ifade edebilmesine, neden-sonuç ilişkisi kurabilmesine, kavram ve sözcük bilgisi gelişimine, akıl yürütmesine yönelik sohbet, tekerleme, bilmece, öykü anlatma, dilbilgisi yapılarına uygun cümle kurma, anlama, ifade etme gibi etkinliklere yer verilmiştir. Matematik etkinliklerinde çocukların, akıl yürütme ve problem çözme becerilerini geliştirmek ve doğal dünyaya ait bilgilerini artırmaya yönelik; sayılar, işlemler, benzerlik, parça-bütün ilişkisi, karşılaştırma, sınıflama ve ayırma, sıralama, model alma ve ilişkiler, geometri ve uzaysal mantık, ölçme, veri toplama ve analizi gibi bilişsel işlemleri yapabilmelerine firsatlar yaratılmıştır. Okuma-yazmaya hazırlık çalışmalarında, ses ve yazı farkındalığını desteklemeye yönelik çalışmalar ile dil ve matematik etkinliklerinde temel alınan becerileri tamamlamaya yönelik çalışmalar hazırlanmıştır. Etkinliklerde çocukların bilişsel yeteneklerini ve erken akademik ve dil becerilerinin geliştirilmesi için amaca uygun somut görsel materyaller ve çalışma sayfaları hazırlanmıştır. Ayrıca, çocukların aktif katılımı için soru-cevap, beyin firtınası ve yaparak yaşayarak öğrenme yöntemlerinden yararlanılmıştır. Bireysel, küçük ve büyük grup çalışmaları yapılması ve mümkün olduğunca her çocuğa söz hakkı verilmesine dikkat edilmiştir. Etkinlik sonrası değerlendirme aşaması için çocukların düşüncelerini açıkça ortaya koyabilmeleri amacıyla açı uçlu sorular hazırlanmıştır. Akademik ve Dil Becerileri Eğitim Programı'nda, 8 haftalık süreç için haftada beş gün uygulanmak üzere toplam 40 tane çocukların bilişsel yeteneklerini ve erken akademik ve dil becerilerinin geliştirilmesine yönelik öğrenme süreçleri hazırlanmıştır. Etkinlik süreleri yaklaşık 30 dakika olacak şekilde planlanmıştır. Etkinliklerin 
çocukların ilgilerine göre değiştirilebilecek esnekliğe sahip olmasına, alışılagelmiş günlük uygulamalardan belirli yönlerde farklılık göstermesine önem verilmiştir. Ayrıca, etkinliklerin ilgi çekici olmasına, çocukları eğlendirirken öğrenmelerini sağlayacak nitelikte olmasına dikkat edilmiştir. Program hazırlandıktan sonra üç okul öncesi ve çocuk gelişimi uzmanı, bir eğitim programları uzmanı ve bir tane de ölçme ve değerlendirme alanından uzmana gönderilerek görüşlerine sunulmuştur. Uzmanların eğitim programı üzerinde yaptıkları eleştiriler ve öneriler dikkate alınarak gerekli düzeltmeler yapılmış ve Akademik ve Dil Becerileri Eğitim Programı'na son şekli verilmiştir.

Akademik ve Dil Becerileri Eğitim Programının Uygulanması ve Verilerin Toplanması: Deney ve kontrol grubundaki çocuklara ve ailelerine ilişkin Genel Bilgi Formu 11-19 Şubat 2013 tarihleri arasında her çocuk için araştırmacı tarafından okullarda çocuklara ait kişisel gelişim dosyalarındaki bilgilere bağlı olarak doldurulmuştur. Araştırmacı ön test uygulamasından önce deney ve kontrol grubundaki çocuklarla öğretmenleri aracılığıyla tanışmış ve çocuklarla sohbet ederek çocukların uygulamayla ilgili kaygılarını gidermeye çalışmıştır. Ayrıca, deney ve kontrol grubu çocuklarının kendisine uyum sağlaması amacıyla yarım gün okulda kalarak günlük programdaki etkinliklere katılmıştır. Daha sonra BYTF-6 ve K-EADBAT testleri deney ve kontrol grubundaki çocuklara testlerin geçerlik ve güvenirlik çalışmasında belirtilen özelliklere uygun biçimde 11-19 Şubat 2013 tarihleri arasında farklı günlerde ön test olarak uygulanmıştır. “Akademik ve Dil Becerileri Ĕgitim Programı”, 20 Şubat 2013 - 16 Nisan 2013 tarihleri arasında sekiz hafta boyunca haftada beş gün ve bir günde ortalama otuz dakika olacak şekilde deney gruplarının kendi öğretmenleri tarafından deney grubunu oluşturan çocuklara uygulanmıştır. Bu süre zarfında kontrol grubunda yer alan çocuklar ise MEB Okul Öncesi Eğitim Programı'nda (2006) yer alan etkinliklere devam etmişlerdir. Akademik ve Dil Becerileri Eğitim Programı uygulanmaya başlanmadan önce, araştırmacı tarafından deney grubunda yer alan öğretmenlere; uygulanacak olan programın özellikleri, amaç ve kazanımları, amaçlara ulaşabilmek için ne gibi durumlar yaratılacağı, çocuklarla nasıl iletişim kurulacağı, bu iletişimin nasıl bir fiziki ortam içinde, hangi uyarıcılarla gerçekleşeceği, hangi yöntem ve tekniklerin kullanılacağı ile ilgili detaylı bir bilgi verilmiştir. Eğitim uygulamaları çocukların eğitim gördükleri kendi sınıflarında gerçekleştirilmiş̧tir. Ayrıca her gün için uygulanması planlanan etkinlik araştırmacı tarafından bir gün önceden deney grubundaki öğretmenlere anlatılmış ve araştırmacının gözleminde öğretmenler etkinlikle ilgili ön deneme yapmışlardır. Deneme çalışması yapılan etkinlik bir gün sonra, öğretmenler tarafından deney grubuna uygulanmıştır. Aynı gün içerisinde sabah ve öğleden sonra eğitim alan iki sınıfa Akademik ve Dil Becerileri Eğitim Programı ayrı ayrı uygulanmıştır. Eğitim programının uygulanması tamamlandıktan sonra 17-24 Nisan 2013 tarihleri arasında ön testlerin yapıldığı aynı ortam ve koşullarda BYTF6 ve K-EADBAT deney ve kontrol grubundaki çocuklara son test olarak uygulanmıştır. Son testlerin uygulanmasından dört hafta sonra eğitimin kalıcılığını test etmek amacıyla araştırmacı tarafindan testler 15-17 Mayıs 2013 tarihleri arasında deney grubundaki tüm çocuklara kalıcılık testi olarak uygulanmıştır.

Nitel Verilerin Toplanması: Akademik ve Dil Becerileri Eğitim Programı iki öğretmen tarafından örnekleme alınan sınıflarda uygulanırken, araştırmacı tarafından doğrudan katılımcı gözlem tekniği ile gözlenmiş ve programda bulunan etkinlikleri uygulama biçimleri, "Akademik ve Dil Becerileri Eğitim Programı Değerlendirme Formu"nda bulunan özelliklere göre gözlemlenmiş ve forma kayıt edilmiştir. Gözlem 40 uygulama arasından tesadüfi örnekleme ile seçilen 10 dil ve okuma-yazmaya hazırlık, 10 matematik etkinliği olmak üzere toplam 20 etkinlik için yapılmıştır. Aynı zamanda öğretmenler tarafından uygulanan bu etkinlikler araştırmacı tarafından kamera ile kayıt altına alınmıştır. Kayıt altına alınan 40 etkinlik (20 etkinlik öğretmen A, 20 
etkinlik öğretmen B) okul öncesi eğitimi alanında başka bir uzmana gönderilerek görüntü analizi yöntemi ile incelenmiş "Akademik ve Dil Becerileri Ĕgitim Programı Değerlendirme Formu"nda belirtilen özelliklere göre değerlendirilerek forma kayıt edilmiştir. Her öğretmen için 20 etkinlik olmak üzere toplam 40 uygulama için gözlem ve görüntü analizi yapılmıştır.

\section{Verilerin Analizi}

Deneysel araştırma modeli gereği deney ve kontrol gruplarının eşitliğini sağlamak üzere, istatistiksel açıdan hipotez testleri gerçekleştirilmiştir. Kullanılacak hipotez testlerinin türünü belirlemek üzere ilk olarak BYTF-6 toplam puanı ile K-EADBAT toplam puanına ait verilerin normal dağılım özelliğini saptamak üzere Kolmogorov-Smirnov testi uygulanmış ve verilerin normal sergilediği belirlenmiştir. Deney ve kontrol gruplarının sayısının 30 kişinin üzerinde olması nedeniyle bu yöntem tercih edilmiştir (Kurtuluş 2010). Buna bağlı olarak deney ve kontrol gruplarının denkliğini belirlemek amacıyla grupların testlerden elde ettikleri puan ortalamaları arasındaki farkın anlamlılı̆̆ "Bă̆ımsız gruplarda $t$ Testi" analizi tekniği ile test edilmiştir. Gruplar arası farklılık incelenirken; anlamlılık seviyesi olarak .01 kullanılmıştır (Kurtuluş 2010; Büyüköztürk 2012). Grupların testlerden elde ettikleri puan ortalamaları arasında istatistiksel olarak anlamlı bir fark olmadığı görülmüştür. Bu sonuçlara göre birbirine denk dört şubenin aynı okulda bulunan iki şubesi deney ve diğer okulda bulunan iki şubesi de kontrol grubu olarak tesadüfi yöntemle atanmıştır. Araştırmada, çocuklara ve anne babalarına ait demografik bilgiler deney ve kontrol gruplarına göre frekans ve yüzde değerleri olarak verilmiştir. Deneysel araştırma deseni gereği, uygulama sonrası son ölçümler yapıldıktan sonra, uygulama etkililiğini saptamak üzere gerekli istatistiksel analizler gerçekleştirilmiştir. Birinci ve ikinci alt problemlere ilişkin olarak deney ve kontrol gruplarının BYTF-6 toplamına ve KEADBAT toplamına ait ön test ve son test puanları kullanılarak yapılan karşılaştırmada grupların ön test sonuçlarına göre düzeltilmiş son test puan ortalamaları arasındaki farkın manidar olup olmadığı, Tek Faktörlü Kovaryans Analizi (one factor ANCOVA) ile test edilmiştir. Hata varyansını azaltması nedeniyle daha büyük bir istatistiksel güç sağlaması ve bir deneyin başlangıcında gruplar arası farkların olduğu durumlarda deneydeki yanlılıkta azalma sağlaması ANCOVA'nın temel avantajlarındandır (Büyüköztürk 2012). Eta-kare değerleri 0.010.06 arasında ise küçük, 0.06-0.14 arasında orta, 0.14 üzeri ise büyük etki büyüklüğünü göstermektedir (Gren, Salkind \& Akey 2000).Üçüncü ve dördüncü alt problemlere ilişkin olarak deney grubunun BYTF-6 toplamına ve K-EADBAT toplamına ait ön test, son test ve kalıcılık testi puanları kullanılarak; grupların ön test, son test ve kalıcılık testi ortalama puanları arasındaki farkı test etmek için tek faktör üzerinde tekrarlı ölçümler için Üç Faktörlü ANOVA (repeated measures) uygulanmıştır. Tekrarlı ölçümler için ANOVA; zaman içerisinde elde edilen düzenli verilerin değerlendirilerek gelecek dönemler için tahminde bulunmayı amaçlayan regrasyon analizidir. Verilerin sürekliliğine dayanarak gelecek tahmin modeli oluşturmayı amaçlamaktadır (Kurtuluş, 2010). Beşinci alt probleme ilişkin olarak doğrudan gözlemci ve değerlendirmeci tarafindan doldurulan "Akademik ve Dil Becerileri Ĕ̈itim Programı Değerlendirme Formu"ndan elde edilen veriler ortalama, mod, medyan ve standart sapma olarak değerlendirilmiş ve öğretmenlerin "Akademik ve Dil Becerileri Eğitim Programı"nı nasıl uyguladıkları "Akademik ve Dil Becerileri Eğitim Programı Değerlendirme Formu"nda bulunan maddelere göre yorumlanmıştır. Doğrudan gözlem; hem nitel hem de nicel araştırma tekniklerinde kullanılan olguların araştırmacı tarafından oldukça yansız olarak olduğu gibi gözlenip kayıt edilmesini kapsamaktadır. Burada söz konusu olan gözlemin kimin tarafından, hangi olgular üzerinde, hangi amaç için, nasıl, hangi bakış açısıyla, nerede, ne zaman ve hangi araçgereç kullanılarak yapıldığının belirtilmesidir. Nitel verilerin analizi kapsamında yer alan 
doküman analizinin bir alt başlığı şeklinde ele alınan görsel analiz, görsel verilerin analiz edilmesi sonucu yapılmaktadır. Görsel analiz, görsel verilerin, simgelerin, sembollerin, işaretlerin açıklanıp yorumlanması şeklinde yapılmaktadır. (Patton 2002; Balc1 2011; Sönmez \& Alacapınar 2013). Nitel verilere ilişkin olarak ise katılımcı gözlemci olarak gözlem yapan araştırmac1 ile görüntü analizi yöntemiyle değerlendirme yapan değerlendirmeci arasındaki tutarlığı belirlemek ve bu şekilde güvenirliği arttırmak amacı ile gözlemci ve değerlendirmeci tarafindan doldurulan iki puan seti arasındaki ilişki Pearson korelasyon katsayısı ile hesaplanmış ve gözlemci ve değerlendirmeci arasındaki tutarlılık incelenmiştir. Bağımsız değerlendirmeciler arası uyum olarak isimlendirilen değerlendirmeciler arası tutarlılık, çok sayıda objenin belirli bir özelliğe ne derece sahip olduğuna ilişkin iki veya daha fazla bağımsız gözlemcinin verdiği puanların güvenirliğini incelemede kullanılmaktadır (Büyüköztürk 2012).

\section{Bulgular}

$\mathrm{Bu}$ bölümde araştırmanın alt problemlerine yönelik olarak deney ve kontrol grubunda yer alan çocukların CATF-6 ve K-EADBAT testlerinden aldıkları puanların karşılaştırılmasına yer verilmiştir.

\section{Birinci ve İkinci Alt Problemlere İlişkin Bulgular}

Araştırmanın birinci ve ikinci alt problemlerine göre deney ve kontrol grubu çocuklarının bilişsel yetenekleri ile dil ve akademik becerileri arasındaki farka ilişkin bulgular tablo 2, 3 ve 4 'te verilmiştir.

Tablo 2. Deney ve Kontrol Gruplarının BYTF-6 Toplam ve K-SEALS Toplam Ön Test Puanlarına Göre Düzeltilmiş Son Test Puanlarına İlişkin Ortalama ve Standart Sapma Değerleri

\begin{tabular}{|c|c|c|c|c|}
\hline Gruplar & Testler & $\mathbf{n}$ & $\overline{\mathbf{X}}$ & ss \\
\hline \multirow{2}{*}{ Deney } & BYTF-6 Toplam & 32 & 65,31 & 8,58 \\
\cline { 2 - 5 } & K-EADBAT Toplam & 32 & 71,63 & 7,71 \\
\hline \multirow{2}{*}{ Kontrol } & BYTF-6 Toplam & 32 & 57,03 & 8,28 \\
\cline { 2 - 5 } & K-EADBAT Toplam & 32 & 54,81 & 10,879 \\
\hline
\end{tabular}

Bilişsel Yetenekler Testi Form-6 Toplam Maximum Puan: 80

Kaufman Erken Akademik ve Dil Becerileri Araştırma Testi Toplamı Maximum Puan: 90

Tablo 2 incelendiğinde deney ve kontrol gruplarının BYTF-6 toplam ve K-EADBAT toplam ön test puanlarına göre düzeltilmiş son test puanlarına ilişkin aritmetikortalamalarının BYTF-6 toplam puanında deney grubunun 65,31, kontrol grubunun ise 57,03 olduğu K-EADBAT toplam puanında deney grubunun 71,63, kontrol grubunun 54,81 olduğu görülmektedir. BYTF6 toplam ve K-EADBAT toplam ortalama puanlarına göre deney grubunun kontrol grubuna göre daha yüksek bir ortalama puana sahip olduğu söylenebilir.

Tablo 3. Deney ve Kontrol Gruplarının BYTF-6 Toplam Son Test Puanlarına İlişkin ANCOVA Sonuçları

\begin{tabular}{|c|c|c|c|c|c|c|}
\hline Varyans Kaynă̆ı & $\begin{array}{c}\text { Kareler } \\
\text { Toplamı }\end{array}$ & Sd & $\begin{array}{c}\text { Kareler } \\
\text { Ortalaması }\end{array}$ & $\mathbf{F}$ & $\mathbf{p}$ & $\mathbf{\eta 2}$ \\
\hline Ön BYTF-6 Toplam & 3674,703 & 1 & 3674,703 & 303,267 &, 000 &, 833 \\
\hline Grup (deney/kontrol) & $\mathbf{1 5 1 3 , 9 2 2}$ & $\mathbf{1}$ & $\mathbf{1 5 1 3 , 9 2 2}$ & $\mathbf{1 2 4 , 9 4 1}$ & $\mathbf{, 0 0 0}$ & $\mathbf{, 6 7 2}$ \\
\hline
\end{tabular}




\begin{tabular}{|c|c|c|c|c|c|c|}
\hline Hata & 739,141 & 61 & 12,117 & & & \\
\hline Toplam & 244999,000 & 64 & & & & \\
\hline $\mathrm{p}<0.01$ & & & & & \\
\hline
\end{tabular}

Tablo 3 incelendiğinde; deney ve kontrol gruplarının ön test BYTF-6 toplam puanlarına göre düzeltilmiş son test BYTF-6 toplam puan ortalamaları arasında istatistiksel olarak anlamlı bir farkın olduğu $\left[\mathrm{F}_{(1,61)}=124,941, \mathrm{p}<0,01\right]$ görülmektedir. Tablo 2'de belirtilen grupların düzeltilmiş BYTF-6 toplam son test puanları arasında yapılan Bonferroni testi sonuçlarına göre deney grubu BYTF-6 toplam puan ortalamas1 $(\overline{\boldsymbol{X}}=65,31)$ ile kontrol grubu $(\overline{\boldsymbol{X}}=57,03)$ arasinda deney grubu lehine anlamlı bir fark bulunmaktadır. Hesaplanan etki büyüklüğ̈ (effect size) ise $\left(\eta^{2}=, 672\right)$ 'dir. Bu durumda uygulanan teknik açısından elde edilen eta-kare değeri $\left(\eta^{2}=, 672\right)$ göz önünde bulundurulduğunda, eta-kare değeri .14'ün üzerinde olduğundan deney grubunda uygulanmış olan Akademik ve Dil Becerileri Eğitim Programı'nın çocukların bilişsel yetenekleri üzerinde olumlu yönde geniş bir etkiye sahip olduğu söylenebilir.

Tablo 4. Deney ve Kontrol Gruplarının K-EADBAT Toplam Son Test Puanlarına İlişkin ANCOVA Sonuçları

\begin{tabular}{|c|c|c|c|c|c|c|}
\hline Varyans Kaynağı & $\begin{array}{c}\text { Kareler } \\
\text { Toplamı }\end{array}$ & Sd & $\begin{array}{c}\text { Kareler } \\
\text { Ortalaması }\end{array}$ & $\mathbf{F}$ & $\mathbf{p}$ & $\mathbf{\eta 2}$ \\
\hline Ön K-EADBAT Toplam & 5034,076 & 1 & 5034,076 & 642,022 &, 000 &, 913 \\
\hline Grup (deney/kontrol) & $\mathbf{4 7 2 5 , 9 1 1}$ & $\mathbf{1}$ & $\mathbf{4 7 2 5 , 9 1 1}$ & $\mathbf{6 0 2 , 7 2 0}$ & $\mathbf{, 0 0 0}$ & $\mathbf{, 9 0 8}$ \\
\hline Hata & 478,299 & 61 & 7,841 & & & \\
\hline Toplam & 265818,000 & 64 & & & & \\
\hline $\mathrm{p}<0.01 \quad$
\end{tabular}

Tablo 4 incelendiğinde; deney ve kontrol gruplarının ön test $K$-EADBAT toplam puanlarına göre düzeltilmiş son test puan ortalamaları arasında istatistiksel olarak anlamlı bir farkın olduğu $\left[\mathrm{F}_{(1,61)}=602,720, \mathrm{p}<0,01\right]$ görülmektedir. Tablo 2 de belirtilen grupların düzeltilmiş $K-E A D B A T$ toplam son test puanları arasında yapılan Bonferroni testi sonuçlarına göre deney grubu $K$ EADBAT toplam puan ortalamas $(\overline{\boldsymbol{X}}=71,63)$ ile kontrol grubu $(\overline{\boldsymbol{X}}=54,81)$ arasinda deney grubu lehine anlamlı bir fark bulunmaktadır. Hesaplanan etki büyüklüğü (effect size) ise $(\eta 2=, 908)$ 'dir. Bu durumda uygulanan teknik açısından elde edilen eta-kare değeri $\left(\eta^{2}=, 908\right)$ göz önünde bulundurulduğunda, eta-kare değeri .14'ün üzerinde olduğundan deney grubunda uygulanmış olan Akademik ve Dil Becerileri Eğitim Programı'nın çocukların erken akademik ve dil becerileri üzerinde olumlu yönde geniş bir etkiye sahip olduğu söylenebilir.

\section{Üçüncü ve Dördüncü Alt Problemlere İlişkin Bulgular}

Araştırmanın üçüncü ve dördüncü alt problemlerine ilişkin BYTF-6 toplamına ait ön test, son test ve kalıcılık testi puanları ile K-EADBAT toplam ön test, son test, kalıcılık testi arasındaki farka ilişkin bulgular tablo 5, 6 ve 7'de verilmiştir.

Tablo 5. Deney Grubunun BYTF-6 Toplam ve K-EADBAT Toplamı Ön test, Son test ve Kalıcılık Testi Puanlarının, Ortalama ve Standart Sapma Değerleri

\begin{tabular}{|l|c|c|c|c|c|c|c|c|c|}
\hline \multirow{2}{*}{} & \multicolumn{4}{|c|}{ Ön test } & \multicolumn{4}{c|}{ Son test } & \multicolumn{3}{c|}{ Kalıcilık Testi } \\
\cline { 2 - 10 } & $\mathbf{n}$ & $\overline{\boldsymbol{X}}$ & $\mathbf{S}$ & $\mathbf{n}$ & $\overline{\boldsymbol{X}}$ & $\mathbf{s}$ & $\mathbf{n}$ & $\overline{\boldsymbol{X}}$ & $\mathbf{s}$ \\
\hline BYTF-6 & 32 & 52,62 & 11,50 & 32 & 65,31 & 8,58 & 32 & 65,56 & 8,50 \\
\hline K-EADBAT & 32 & 52,41 & 9,193 & 32 & 71,63 & 7,71 & 32 & 71,78 & 7,43 \\
\hline
\end{tabular}


Tablo 5 incelendiğinde, deney grubunun BYTF-6 toplamı aritmetik ortalamalarının ön test için 52,62 , son test için 65,31 ve kalıcılık testinin 65,56 olduğu; $K$-EADBATtoplamı aritmetik ortalamalarının ön test için 52,41 , son test için 71,63 ve kalıcılık testinin 71,78 olduğu belirlenmiştir.

Tablo 6. Deney Grubunun BYTF-6 Toplam Ön test, Son test ve Kalıcıllk Testi Puanlarına İlişkin Tekrarlı Ölçümler İçin Üç Faktörlü Anova Sonuçları

\begin{tabular}{|c|c|c|c|c|c|c|c|}
\hline Varyansın Kaynağı & K.T. & Sd & K.O. & $\mathbf{F}$ & $\mathbf{p}$ & $\eta^{\mathbf{2}}$ & $\begin{array}{c}\text { Farkın } \\
\text { Kaynağı }\end{array}$ \\
\hline $\begin{array}{c}\text { Ölçüm (ön test, son test, } \\
\text { kalıcılık testi) }\end{array}$ & $\mathbf{3 5 0 3 , 0 8 3}$ & $\mathbf{2}$ & $\mathbf{1 7 5 1 , 5 4 2}$ & $\mathbf{1 4 7 , 7 6 6}$ & $\mathbf{, 0 0 0}$ & $\mathbf{8 3 0}$ & $1-2$ \\
\hline Hata & 734,917 & 62 & 11,853 & & & & $1-3$ \\
\hline Toplam & 4238 & 64 & 1763,395 & & & & \\
\hline
\end{tabular}

$\mathrm{p}<0.01$ 1: ön test, 2: son test, 3: kalıc1lık testi

Tablo 6 incelendiğinde, deney grubunun BYTF-6 toplamı ön test, son test ve kalıc1lık testi puanları arasında yapılan analizde, geniş etki $\left(\eta^{2}=0,830\right)$ düzeyinde anlamlı farklılık $\left[\mathrm{F}_{(2,62)}=147,766 \mathrm{p}<0,01\right]$ bulunmuştur. Bu sonuçlara göre deney grubunda uygulanan akademik ve dil becerileri eğitim programının uygulanması sonucunda yapılan son test ortalama puanı ve son testin uygulanmasından dört hafta sonra yapılan kalıcılık testi ortalama puanları ön test ortalama puanlarına göre daha yüksektir. Ancak, son test ve kalıcılık testi puanları arasındaki fark anlamlı bulunmamıştır. Son testten dört hafta sonra yapılan kalıcılık testinde BYTF-6 toplam puanındaki artış akademik ve dil becerileri eğitim programının etkisinin devam ettiğini göstermektedir.

Tablo 7. Deney Grubunun K-EADBAT Toplam Ön test, Son test ve Kalıc1lk Testi Puanlarına İlişkin Tekrarlı Ölçümler İçin Üç Faktörlü Anova Sonuçları

\begin{tabular}{|c|c|c|c|c|c|c|r|}
\hline Varyansın Kaynağı & K.T. & Sd & K.O. & F & $\mathbf{p}$ & $\eta^{2}$ & $\begin{array}{c}\text { Farkın } \\
\text { Kaynağı }\end{array}$ \\
\cline { 1 - 5 } $\begin{array}{c}\text { Ölçüm (ön test, son test, } \\
\text { kalıcılık testi) }\end{array}$ & $\mathbf{7 9 4 4 , 2 7 1}$ & $\mathbf{2}$ & $\mathbf{3 9 7 2 , 1 3 5}$ & $\mathbf{6 0 9 , 9 9 4}$ & $\mathbf{, 0 0 0}$ & $\mathbf{, 9 5 2}$ & $1-2$ \\
\cline { 1 - 5 } Hata & 403,729 & 62 & 6,512 & & & & $1-3$ \\
\hline Toplam & 8348 & 64 & 3978,647 & & & & \\
\hline
\end{tabular}

$\mathrm{p}<0.01$ 1: ön test, 2: son test, 3: kalıc1lık testi

Tablo 7 incelendiğinde, deney grubunun K-EADBAT toplamı ön test, son test ve kalıcılık testi puanları arasında yapılan analizde, geniş etki $\left(\eta^{2}=\right.$,952) düzeyinde anlamlı farklılık $\left[\mathrm{F}_{(2,62)}=609,994 \mathrm{p}<0,01\right]$ bulunmuştur. Bu sonuçlara göre deney grubunda uygulanan akademik ve dil becerileri eğitim programının uygulanması sonucunda yapılan son test ortalama puanı ve son testin uygulanmasından dört hafta sonra yapılan kalıcılık testi ortalama puanları ön test ortalama puanlarına göre daha yüksektir. Ancak, son test ve kalıcılık testi puanları arasındaki fark anlamlı bulunmamıştır. Son testten dört hafta sonra yapılan kalıcılık testinde K-EADBAT toplam puanındaki artış akademik ve dil becerileri eğitim programının etkisinin devam ettiğini göstermektedir.

\section{Beşinci Alt Probleme İlişkin Nitel Bulgular}

Araştırmanın beşinci alt problemine ilişkin nitel verilere yönelik bulgular tablo 8'de verilmiştir 
Tablo 8. Akademik ve Dil Becerileri Eğitim Programı'nın Öğretmen A-B Tarafından Uygulanmasına İlişkin Gözlem ve Görüntü Analizi Sonuçlarına Göre Araştırmacı ve Diğer Puanlayıcı Tarafından Doldurulan Akademik ve Dil Becerileri Eğitim Programı Değerlendirme Formu Sonuçlarına İlişkin Ortalama, Mod, Medyan ve Standart Sapma Değerleri

\begin{tabular}{|c|c|c|c|c|c|c|c|c|c|c|c|c|c|c|c|c|c|c|c|c|}
\hline \multirow{3}{*}{ 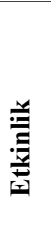 } & \multicolumn{10}{|c|}{ Öğretmen A } & \multicolumn{10}{|c|}{ Öğretmen B } \\
\hline & \multicolumn{5}{|c|}{ Araştırmacı } & \multicolumn{5}{|c|}{ Puanlayıcı } & \multicolumn{5}{|c|}{ Araştırmacı } & \multicolumn{5}{|c|}{ Puanlayıcı } \\
\hline & $=$ & $\dot{\Xi}$ & 离 & 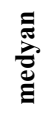 & $\tilde{n}$ & $=$ & $\dot{\Xi}$ & छ̊ & 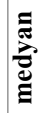 & 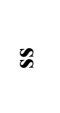 & $=$ & $\dot{\Xi}$ & : & 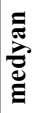 & $n$ & $=$ & $\dot{ \pm}$ & ఏ & 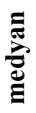 & $\ddot{n}$ \\
\hline 1 & 20 & 1 & 1 & 1 &, 00 & 20 & 1 & 1 & 1 &, 00 & 20 & ,90 & 1 & 1 &, 31 & 20 & ,90 & 1 & 1 & ,31 \\
\hline 2 & 19 & 1 & 1 & 1 &, 00 & 19 & 1 & 1 & 1 &, 00 & 19 &, 89 & 1 & 1 &, 31 & 19 & 89 & 1 & 1 &, 31 \\
\hline 3 & 19 & 1 & 1 & 1 & ,00 & 19 & 1 & 1 & 1 & ,00 & 19 & ,95 & 1 & 1 &, 23 & 19 & 89 & 1 & 1 &, 31 \\
\hline 4 & 19 & 1 & 1 & 1 & , 00 & 19 & 1 & 1 & 1 & ,00 & 19 & ,95 & 1 & 1 & ,23 & 19 & ,95 & 1 & 1 & ,23 \\
\hline 5 & 18 & 1 & 1 & 1 & , 00 & 18 & 1 & 1 & 1 &, 00 & 18 & 1 & 1 & 1 &, 00 & 18 & 1 & 1 & 1 &, 00 \\
\hline 6 & 19 & 1 & 1 & 1 &, 00 & 19 & 1 & 1 & 1 & ,00 & 19 & 1 & 1 & 1 &, 00 & 19 & 1 & 1 & 1 &, 00 \\
\hline 7 & 19 & 1 & 1 & 1 &, 00 & 19 & 1 & 1 & 1 & ,00 & 19 & ,95 & 1 & 1 & ,23 & 19 & ,95 & 1 & 1 & ,23 \\
\hline 8 & 19 & 1 & 1 & 1 & ,00 & 19 & 1 & 1 & 1 & , 00 & 18 & 1 & 1 & 1 &, 00 & 19 & 1 & 1 & 1 & ,00 \\
\hline 9 & 19 & 1 & 1 & 1 & ,00 & 19 & 1 & 1 & 1 & ,00 & 19 & 1 & 1 & 1 & , 00 & 19 & ,95 & 1 & 1 & 23 \\
\hline 10 & 18 & ,94 & 1 & 1 & ,24 & 18 & 1 & 1 & 1 & ,00 & 18 & ,89 & 1 & 1 &, 32 & 18 & ,89 & 1 & 1 &, 32 \\
\hline 11 & 19 & 1 & 1 & 1 & 00 & 19 & 1 & 1 & 1 &, 00 & 19 & 1 & 1 & 1 & 00 & 19 & ,95 & 1 & 1 & ,23 \\
\hline 12 & 19 & 1 & 1 & 1 & 00 & 19 & 1 & 1 & 1 &, 00 & 19 & ,89 & 1 & 1 & ,31 & 19 & 84 & 1 & 1 & ,37 \\
\hline 13 & 19 & 1 & 1 & 1 & , 00 & 19 & 1 & 1 & 1 & ,00 & 19 & 1 & 1 & 1 & , 00 & 19 & ,95 & 1 & 1 & 23 \\
\hline 14 & 18 & ,94 & 1 & 1 & ,24 & 18 & 1 & 1 & 1 &, 00 & 18 &, 78 & 1 & 1 & ,43 & 18 & ,78 & 1 & 1 & ,43 \\
\hline 15 & 18 & 1 & 1 & 1 & 00 & 18 & 1 & 1 & 1 &, 00 & 18 &, 89 & 1 & 1 &, 32 & 18 & ,94 & 1 & 1 & 24 \\
\hline 16 & 18 & 1 & 1 & 1 & , 00 & 18 & 1 & 1 & 1 & ,00 & 18 & 1 & 1 & 1 & , 00 & 18 & 1 & 1 & 1 & , 00 \\
\hline 17 & 18 & 1 & 1 & 1 & 00 & 18 & 1 & 1 & 1 &, 00 & 18 &, 89 & 1 & 1 &, 32 & 18 &, 89 & 1 & 1 &, 32 \\
\hline 18 & 19 & 1 & 1 & 1 & , 00 & 19 & 1 & 1 & 1 & ,00 & 19 & 1 & 1 & 1 & , 00 & 19 & 1 & 1 & 1 & , 00 \\
\hline 19 & 19 & 1 & 1 & 1 & 00 & 19 & 1 & 1 & 1 & ,00 & 19 & 1 & ,95 & 1 & ,23 & 19 & 95 & 1 & 1 & 23 \\
\hline 20 & 19 & 1 & 1 & 1 & 00 & 19 & 1 & 1 & 1 &, 00 & 19 & 1 &, 84 & 1 &, 37 & 19 &, 84 & 1 & 1 &, 37 \\
\hline
\end{tabular}

Tablo 8 incelendiğinde her bir etkinliğin öğretmen A tarafindan uygulanmasına yönelik olarak araştırmacı tarafindan almış olduğu $\mathrm{n}$ değerinin 18-20 arasında, ortalama değerinin ,94-1 arasında değiştiği, mod ve medyan değerlerinin 1, standart sapma değerlerinin ise ,00-.24 arasında değiştiği görülmektedir. Her bir etkinlik için puanlayıcı tarafından almış olduğu n değerinin 18-20 arasında değiştiği, ortalama, mod ve medyan değerlerinin 1, standart sapma değerlerinin ise ,00 olduğu tespit edilmiştir.Her bir etkinliğin öğretmen B tarafindan uygulanmasına yönelik olarak araştırmacı tarafindan almış olduğu n değerinin 18-20 arasında, ortalama değerinin ,78-1 arasında, mod değerinin ,84-1 arasında değiştiği, medyan değerlerinin 1, standart sapma değerlerinin ise ,00-,43 arasında değiştiği görülmektedir. Her bir etkinlik için puanlayıcı tarafından almış olduğu n değerinin 18-20 arasında değiştiği, ortalama değerinin ,781 , mod ve medyan değerlerinin 1 , standart sapma değerlerinin ise ,00-,43 arasında değiştiği tespit edilmiştir.

Ayrıca, Akademik ve Dil Becerileri Eğitim Programı Değerlendirme Formu puanlayıcı güvenirliği korelasyon değerlerinin öğretmen A için ,931, öğretmen B için ise ,902 olarak 
belirlenmiştir. Araştırmacı ve değerlendirmeci arasındaki ilişkinin $\mathrm{p}<0.01$ düzeyinde anlamlı olduğu görülmektedir. Akademik ve Dil Becerileri Eğitim Programı'nın uygulanması açısından gözlem ve görüntü analizi güvenirlik katsayılarının oldukça yüksek ve birbirine yakın değerlerden oluştuğu görülmektedir. Buna göre, Akademik ve Dil Becerileri Eğitim Programı Değerlendirme Formu sonuçlarının puanlayıcı güvenirliği açısından gözlemci ve görüntü analizi yapan değerlendirmeci arasında tutarlılık olduğu söylenebilir.

\section{Tartışma}

Okul öncesi dönemdeki çocukların, aile ortamında ve okulda; bilinçli ve eğitimli insanlarla, nesnelerle ve olaylarla etkileşime girerek, yeni bilgiler elde ettikleri, bu bilgileri eski bilgileri ile kıyaslayarak yeni anlamlara ve yeni sonuçlara ulaştıkları, olaylar arasında neden sonuç ilişkisi kurdukları, neyi, neden, nasıl yaptıklarını sorguladıkları, yaparak yaşayarak, eğlenceli ve oyun temelli öğrenme etkinliklerine katılmaları onların dil ve akademik becerilerini geliştirmelerini ve bu alanda başarılı olabilmelerini sağlamaktadır (Mclachan, Fleer \& Edwards 2013; Wood 2013). Akademik ve dil becerileri eğitim programının 61-66 aylık çocukların bilişsel yeteneklerine ve erken akademik ve dil becerilerine etkisinin incelenmesi amacıyla yapılan araştırmanın sonuçları, deney grubunda uygulanmış olan Akademik ve Dil Becerileri Eğitim Programı'nın çocukların bilişsel yetenekleri üzerinde olumlu yönde geniş bir etkiye sahip olduğunu göstermektedir. Bu durum eğitim programına katılan çocukların sözel ve sayısal muhakeme puanlarının akademik ve dil becerileri eğitim programına katılmayan çocukların puanlarından anlamlı düzeyde yüksek olduğunu göstermektedir. Araştırmanın bu bulgusu alan yazında yapılan erken müdahale ile ilgili yapılmış çalışmalarla tutarlıdır. White ve Manning (1994) sözel yapılandırma eğitiminin, çocukların verilen durumlar arasındaki ilişkiyi bulma ve ilişkiye bağlı olarak çıkarımda bulunma becerisi, analojiler arasında daha kolay ilişki kurabilme ve analoji problemlerini daha kolay çözebilmeleri üzerinde etkili olduğunu ortaya çıkarmıştır. Munro (1998) fonolojik farkındalık eğitiminin çocukların sözel muhakeme yeteneklerini geliştirdiğini belirtmiştir. Hager ve Hasselhorn (1998), Klauer tarafindan oluşturulan bilişsel eğitim programı ile ilgili yetmiş araştırmanın meta-analizini yapmışlar ve Klauer tarafından hazırlanan bilişsel eğitim programının çocukların tümevarıma dayalı muhakeme yeteneğini desteklediğini ve akademik başarılarını artırdığını tespit etmişlerdir. Beck ve McKeown (2007) araştırmalarında, geliştirdikleri sözcük dağarcığı eğitim programının alt sosyoekonomik düzeydeki okul öncesi dönem çocuklarının sözel ifadeleri kavrama ve sözel ifadelere bağlı olarak çıkarımda bulunma becerilerini geliştirmede etkili olduğunu belirlemişlerdir. Ünal (2007) anasınıfına devam eden altı yaş grubu çocuklara uygulanan kısa süreli bellek eğitim programının çocukların kısa süreli bellek kapasitelerinin artmasına etki ettiğini; Kidd, Pasnak, Gadzichowski, Ferral-Like ve Gallington (2008) sayı sayma, nesneleri toplama, nesneleri miktarlarına göre karşılaştırma, sayıları sıralama çalışmalarını içeren matematik eğitim programının, çocukların muhakeme yeteneklerini geliştirmede etkili olduğunu ortaya koymuşlardır. Welsh ve arkadaşları (2010) okul öncesi dönemde, çalışan bellek ve dikkat kontrolünün hızlı okuma yazma yeteneğine öncülük ettiğini ve genel bilişsel yeteneklerdeki gelişimin anaokulunda matematik ve okuma yazma yeteneğine eşsiz bir katkı sağladığı, özel yetenekleri kontrol altına aldığını belirtmişlerdir. Akademik öğrenme için çalışan bellek ve dikkat kontrolünün önemine 1şık tutmuş ve okula başlangıçtan önceki erken çocukluğun etkilerini ortaya çıkarmıştır. İnal (2011) altı yaş çocuklarına uygulanan muhakeme eğitim programının çocukların sözel, sayısal, sözel olmayan muhakeme becerilerine anlamlı derecede etkili olduğunu tespit etmiştir. Özyürek ve Ömeroğlu (2013) bellek eğitimi programının okul öncesi eğitim kurumuna devam eden altı yaş grubundaki çocukların genel bellek, dikkat, öğrenme ve tanıma puanlarında etkili olduğunu tespit etmiştir. 
$\mathrm{Bu}$ bulgulardan da anlaşıldığ 1 gibi çocukların bilişsel yeteneklerinin geliştirilmesinde, etkin olarak katıldıkları, bellek, muhakeme, problem çözme, akademik ve dil becerilerine yönelik eğitimlerin etkisinin olduğu düşünülmektedir.

Araştırmanın başka bir bulgusunda deney grubunda uygulanmış olan Akademik ve Dil Becerileri Eğitim Programı'nın çocukların erken akademik ve dil becerileri üzerinde olumlu yönde geniş bir etkiye sahip olduğu tespit edilmiştir. Bu durum eğitim programına katılan çocukların sözcük bilgisi, alıcı ve ifade edici dil becerileri, sayılar harfler, sözcükler ve telaffuz becerilerini oluşturan erken akademik ve dil becerileri puanlarının akademik ve dil becerileri eğitim programına katılmayan çocukların puanlarından anlamlı düzeyde yüksek olduğunu göstermektedir. İlgili literatür incelendiğinde, Young-Loveridge (2004) oyunlar ve sayı kitaplarının kullanıldığı eğitim programın erken çocukluk dönemdeki çocukların sayı algılamaları üzerinde oldukça yüksek oranda anlamlı değişmelere neden olduğunu tespit etmiştir. Turhan (2004) anasınıfına devam eden alt sosyo-ekonomik düzeydeki çocuklara uygulanan matematiksel kavramları destekleyici eğitim programının çocukların cümle ve sayı olgunluk becerilerini olumlu yönde etkilediğini belirlemiştir. Türkmenoğlu (2005) 60-72 aylık çocuklar için geliştirilen "Oyun Yoluyla Matematik Kavramlarını Kazandırma Programi"nın deney grubundaki çocukların, kontrol grubu çocuklarına göre matematik becerilerinde artışa neden olduğunu tespit etmiştir. Şimşek (2007) Türkçe dil eğitim programının okuma olgunluğu düzeyine etkisi olduğunu saptamıştır. Yazıcı (2007) tarafından birinci ve ikinci dili Türkçe olan iki dilli çocukların Türkçe'yi kazanımlarına dil merkezli okul öncesi eğitim programının çocukların objeli ve resimli zıt ilişkiler, cümle tamamlama, meslekler, maddeler, objesiz zıt ilişkiler, on rengin adını söyleme, on iki mastar, lügatçe becerilerini arttırmada önemli olduğu saptamıştır. Elliot ve Olliff (2008) Erken Okuma ve Öğrenme Modelleri Programı'nın çocuklardaki alfabe bilgisi ile erken okuma yazma becerilerinin arttırdığını tespit etmişlerdir. Ayrıca çocukların alfabeyi tanıması ile daha sonraki okuma başarıları arasında güçlü bir ilişki olduğunu belirlemişlerdir. Gober (2008) anasınıfına devam eden çocuklara uygulanan yazı farkındalığı programının etkisi incelenmiştir. Araştırmanın sonucunda doğrudan eğitim programı ile yazı farkındalığı eğitimi verilen deney grubundaki çocukların, dolaylı olarak yazı farkındalığı eğitimi alan kontrol grubundaki çocuklara göre hem yazı farkındalığı hem de okuma becerilerinde istatistiksel olarak daha başarılı olduğunu belirlemiştir. Edmonds, O’Donoghue, Spano, Algozzine (2009) yaptıkları araştırmada, okul öncesi dönemdeki çocuklara uygulanan altı haftalık okuryazarlık yaz programının çocukların ilk sesi aynı olan sözcükler, son sesi olan sözcükler, harf bilgisi ve resim isimlendirme becerilerini geliştirdiğini ortaya koymuşlardır. Sarıtaş (2010) Milli Eğitim Bakanlığı Okul Öncesi Eğitim Programına uyarlama çalışması yapılmış GEMS (Great Exploration in Math and Science) Fen ve Matematik Programının altı yaş çocuklarının kavram edinimleri ve okula hazır bulunuşluk düzeylerinin geliştirilmesinde ve çocukların tüm gelişim alanlarında (zihinsel/dil, sosyal/duygusal, fiziksel, öz bakım) etkili olduğunu belirtmiştir. Justice ve arkadaşları (2010) "Read It Again! (RIA)" (Yeniden Oku) programına katılan çocukların dil ve okuryazarlık becerilerinde kontrol grubundaki çocuklar ile karşılaştırıldığında daha fazla puan ortalamasına sahip olduğu tespit etmiş̧lerdir. Ayrıca bilgisayar destekli eğitim programının geometrik şekil kavramlarını öğrenmelerinde (Kesicioğlu 2011), Küçük Çocuklar için Büyük Matematik Eğitim Programı'nın çocukların erken matematik becerilerine (Çelik \& Kandır 2013) ve okuma yazma becerilerini destekleyici duyu eğitimi programının çocukların okuma yazma becerilerine (Yazıcı \& Kandır 2014) okuma yazmaya hazırlık eğitim programının çocukların yazı farkındalığı, ses farkındalığı ve ilkokuldaki okuma-yazma becerileri puanlarına (Bayraktar \& Temel 2014) etkisi olduğu ortaya konulmuştur. Bu bulgulardan da anlaşıldığı gibi çocukların erken akademik ve dil becerilerinin geliştirilmesinde, çocukların etkin olarak katıldığı dil, 
matematik, okuma-yazmaya hazırlık etkinliklerine yönelik yapılan deneysel çalışmaların etkisinin olduğu görülmektedir. Bu durum araştırmanın bulguları ile paralellik göstermektedir.

MEB (2006) Okul Öncesi Eğitim Programı'ndaki amaç, kazanımlar ve dil, matematik, okuma yazmaya hazırlık gibi etkinlikler temel alınarak hazırlanmış olan "Akademik ve Dil Becerileri Eğitim Programı"nın çocukların bilişsel yeteneklerinin ve erken akademik ve dil becerilerinin gelişimi üzerinde oldukça etkili olmasının program içerisinde; çocukların aktif katılımının sağlandığı, somut materyallerle deneme-yanılma, problem çözme, analiz, sentez, değerlendirme yaptıkları, sözel ve sayısal kavramlara yönelik beceriler ve çalışmalar üzerinde durulmasına, çocukların muhakemenin temelini oluşturan becerilere yönelik deneyimleri yaparak ve yaşayarak kazanmalarını sağlayan çalışmaların yapılmasının etkili olabileceği düşünülmektedir. Bununla birlikte, program kapsamında çocukların önce günlük yaşantılarındaki deneyimlerinden yola çıkılarak, oyun yoluyla, eğlenceli bir şekilde gerçek materyallerle çalışmalar yapmalarının sözcüklerin ve kavramların adlandırılmasının, verilen özelliklere bağlı olarak çıkarımda bulunulmasının, sözel-sayısal neden-sonuç ilişkilerini kurmaya yönelik çalışmalar yapılmasının, bilmeceler, karikatürler, resimli kartlar, görsel ve işitsel uyaranların bulunduğu etkinliklere yer verilmesinin, somut materyallerle eşleştirme, karşılaştırma, sınıflama, sıralama, sayısal işlemler, parça-bütün, örüntü oluşturma, ölçme, uzaysal algı, veri analizi ve grafik oluşturma çalışmalarının yapılmasının, hece ve uyak farkındalığı ile yazı farkındalığını geliştirmeye yönelik kitap okuma etkinliklerinin yapılmasının, harfler ve sesleri ile ilgili etkinlikler yapılmasının, çocukları yazı ile karşılaştırarak onların yazı ve sözel dil arasındaki bağlantıyı kurmalarına yardım edilmesinin ve kitap kavramları (önü-arkası, altı-üstü, başlı̆̆1, yazarı, yazı yönü vb.) ile ilgili çalışmalar yapılmasının ve çalışma kağıtlarının çocukların bilişsel yetenekleri ve erken akademik ve dil becerilerinin gelişmesinde etkili olduğu düşünülmektedir.

Araştırmanın diğer bir bulgusuna göre erken akademik ve dil becerileri eğitim programına katılan çocukların bilişsel yetenekler ve erken akademik ve dil becerileri son test ve kalıcılık testi ortalama puanları ön test ortalama puanlarına göre daha yüksektir. Ancak, son-test ve kalıcılık testi puanları arasında anlamlı bir farklılığa rastlanmamıştır. Bu sonuç, erken akademik ve dil becerileri eğitim programına katılan çocuklarda programın etkisinin devam ettiğini göstermektedir. Erken akademik ve dil becerileri eğitim programı çocukların bilişsel yeteneklerini ve erken akademik ve dil becerilerini arttırmış ve becerilerini kullanmada deneyim kazanmalarını sağlamış olabileceği düşünülmektedir.

Araştırmanın nitel bulgularına göre öğretmen A ve B'nin Akademik ve Dil Becerileri Eğitim Programı'nı uygularken; eğitim ortamını uygun şekilde düzenlediği, güvenliği sağladığı, etkinliğe başlamadan önce çocuğa etkinlikle ilgili bilgi vererek dikkatini çektiği, etkinliğin uygulanması sırasında, anlaşılır açıklamalar yaparak uygun yönergeler verdiği, etkinliği yöntemine uygun olarak, materyalleri etkili bir şekilde kullanarak, aşamasına uygun olarak uyguladığı, ses tonu, beden dilini kullanarak etkinliklere çocuklarla birlikte katıldığı, zamanı verimli kullandığı, tekerleme, şiir, şarkı vb. özelliğine uygun olarak söylediği/oynadığ 1 , hedef sözcüklere çocukların dikkatini çektiği ve açıklayıcı bilgiler verdiği, etkinlikteki teknolojik / somut materyalleri gerektiği gibi kullandığı, etkinlik süresince ve sonrasında değerlendirme sorularını çocuklara yönelttiği ve dönütler verdiği ve değerlendirme sürecinde her çocuğa eşit fırsat tanıdığı söylenebilmektedir. Ayrıca Akademik ve Dil Becerileri Eğitim Programı Değerlendirme Formu puanlayıcı güvenirliği korelasyon değerlerinin oldukça yüksek ve birbirine yakın değerlerden oluştuğu görülmektedir. Buna göre, Akademik ve Dil Becerileri Eğitim Programı Değerlendirme Formu sonuçlarının puanlayıcı güvenirliği açısından gözlemci ve görüntü analizi yapan değerlendirmeci arasında tutarlılık olduğu söylenebilir. 
Akademik ve dil becerileri eğitim programının 61-66 aylık çocukların bilişsel yetenekleri ile erken akademik ve dil becerilerini olumlu yönde etkilediği ve bu etkinin izleme testine göre devam ettiği sonucuna dayanarak, eğitim programının uygulanmasında aynı yöntem ve teknikler kullanılarak farklı sosyo-kültürel düzeyde yetişen bireyler ve farklı ve daha geniş örneklem grubuna uygulanarak sonuçları değerlendirilebilir. Ailelere çocukların bilişsel yeteneklerini ve erken akademik ve dil becerilerini desteklemeye yönelik seminerler ve toplantılar düzenlenebilir. Eğitimciler, bilişsel yetenekler ile dil ve akademik beceriler açısından başarısı düşük olan çocuklar için bireysel destek programları hazırlayabilirler. Eğitimciler, hazırladıkları çocukların dikkat, algı, bellek, problem çözme ve muhakeme yapabilecekleri ve aynı zamanda dil ve akademik becerileri kazanabilecekleri biçimde bütünleştirilmiş öğrenme süreçlerine ağırlık verebilirler. Uzunlamasına çalışmalar yapılarak akademik ve dil becerileri eğitim programının çocukların ileri akademik başarısı üzerindeki etkisi incelenebilir. 


\section{KAYNAKÇA}

Amsel E. \& Byrnes J. P. (2002). Language, Literacy and Cognitive development the Development and Consequences of Symbolic Communication. New Jersey 2002. Doi: 10.1016/j.ecresq.2004.10.003

Anlıak O. Ş. (2004). Farklı Eğitim Yaklaşımları Uygulayan Okul Öncesi Eğitim Kurumlarında Kişiler Arası Bilişsel Problem Çözme Becerisi Programının Etkisinin İncelenmesi. Yayımlanmamış Doktora Tezi. Ege Üniversitesi, Sosyal Bilimler Enstitüsü, İzmir 2004.

Aram D. \& Biron S. (2004). "Joint Storybook Reading and Joint Writing Interventions Among Low SES Preschoolers: Differential Contributions to Early Literacy". Early Childhood Research Quarterly 19/4 (2004) 588-610.

Balcı A. (2011). Sosyal Bilimlerde Araştırma Yöntem, Teknik ve İlkeler. Ankara 2011.

Bayraktar V. \& Temel F. (2014). “Okuma-yazmaya Hazırlık Eğitim Programı'nın Çocukların Okuma Yazma Becerilerine Etkisi”. Hacettepe Üniversitesi Eğitim Fakültesi Dergisi 29/3 (2014) 08-22.

Beaty J. J. (2014). Preschool Appropriate Practices Environment, Curriculum and Development. Belmont 2014.

Beck I. L. \& McKeown M. G. (2007). "Increasing Young Low-Income Children's Oral Vocabulary Repertoires Through Rich and Focused Instruction". The Elementary School Journal 107/3 (2007) 251-271.

Bidell T. R. \& Fischer K. W. (2005). "Cognitive Development in Educational Context: İmplications of Skill Theory". Eds. A. Demetriou, M. Shayer \& A. Efklides, Neo-Piagetian Theories of Cognitive Development (2005) 9-29. New York.

Browne A. (2007). Teaching and Learning, Communication, Language and Literacy. Great Britain 2007.

Burger K. (2010). "How Does Early Childhood Care and Education Affect Cognitive Development? An International Review of the Effects of Early Interventions for Children from different Social Backgrounds". Early Childhood Research Quarterly 25/2 (2010) 140-165.

Doi: 10.1016/j.ecresq.2009.11.001

Burgess S. R. (2002). "The Influence of Speech Perception, Oral Language Ability, the Home Literacy Environment and Pre-Reading Knowledge on the Growth of Phonological Sensitivity: a One-Year Longitudinal Investigation". Reading and Writing: An Interdisciplinary Journal 15 (2002) 709-737. Doi: 10.1023/A:1020954606695

Büyüköztürk Ş. (2012). Sosyal Bilimler İçin Veri Analizi El Kitabı. Ankara 2012.

Büyüköztürk Ş., Kılıç-Çakmak E., Akgün E. Ö., Karadeniz Ş. \& Demirel F. (2012). Bilimsel Araştırma Yöntemleri. Ankara 2012 ${ }^{13}$.

Campbell A. F., Pungello P. E., Miller-Johnson S., Burchinal M. \& Ramey T. C. (2001). "The Development of Cognitive and Academic Abilities: Growth Curves from an Early Childhood Educational Experiment." Developmental Psychology 37/2 (2001) 231-242.

Charlesworth R. \& Lind K. K. $\left(2007^{5}\right)$. Math \& Science for Young Children. USA 2007.

Churcman S. L. (2007). Bringing Math Home: A Parents' Guide to Elementary School Math: Game, Activities, Projects. Chicago 2007.

Clements D. H. \& Sarama J. (2009). Learning and Teaching Early Math. New York 2009.

Cohen D. (2013). How The Child's Minds Develop Develops. New York 2013.

Cresswell J. W. \& Plano-Clark V. L. (2007). Designing and Conducting Mixed Methods Research. California 2007.

Çelik M. \& Kandır A. (2013). "61-72 Aylık Çocukların Matematik Gelişimine 'Küçük Çocuklar İçin Matematik' (Big Math for Little Kids) eğitim Programının Etkisi”. Kuramsal Eğitim Bilim Dergisi 6/4 (2013) 551-567. Doi: http://dx.doi.org/10.5578/keg.6712

Dehn, M. J. (2008). Working Memory and Academic Learning Assessment and Intervention. New Jersey 2008.

Edmonds E., O'Donoghue C., Spano S. \& Algozzine R. F. (2009). "Learning When School is Out". The Journal of Educational Research 102/3 (2009) 213-221. 
Elliot M. E. \& Olliff B. C. (2008). "Developmentally Appropriate Emergent Literacy Activities for Young Children: Adapting the Early Literacy and Learning Model". Early Childhood Education Journal 35 (2008) 551-556.

Ezell H. K. \& Justice L. M. (2005). Shared Story Book Building Young Children's Language and Emergent Literacy Skill. Maryland 2005.

Furnes B. \& Samuelsson S. (2009). "Preschool Cognitive and Language Skills Predicting Kindergarten and Grade 1 Reading and Spelling: A-Cross-Linguistic Comparison". Journal of Research in Reading 32/3 (2009) 275-292. Doi: 10.1002/dys.401

Garton A. F. (2004). Exploring Cognitive Development: the Child as Problem Solver. Oxford 2004.

Gober C. M. (2008). Concepts About Print and the Development of Early Reading Strategies in Kindergarten. Ph.D. Thesis. Walden University, Minneapolis, USA 2008.

Green S. B., Salkind N. J. \& Akey T. M. (2000). Using SPSS for Windows Analyzing and Understanding Data. New Jersey 2000.

Groome D., Dewart H., Esgate A., Gurney,K., Kemp R. \& Towell N. (2005). An Introduction to Cognitive Psychology Processes and Disordes. Hove 2005.

Hager W. \& Hasselhorn M. (1998). "The Effectiveness of the Cognitive Training for Children from a Differential Perspective: A Meta-Evaluation”. Learning and Instruction 8/5 (1998) 411-438. Doi: 10.1016/S0959-4752(98)00003-6

Heffelfinger A. K. \& Mrakotsky C. (2006). "Cognitive Development". Ed. J. L. Luby, Handbook of Preschool Mental Health, Development, Disorders, and Treatment (2006) 45-60. New York.

Holmes J. \& Adams J. (2006). "Working Memory and Children's Mathematical Skills: Implications for Mathematical Development and Mathematics Curricula". Educational Psychology 26/3 (2006) 339366. Doi:10.1080/01443410500341056

İnal G. (2011). Bilişsel Yetenekler Testi Form-6'nın Geçerlik Güvenirlik Çalışması ve Altı Yaş Çocuklarının Bilişsel Yeteneklerine Muhakeme Eğitim Programının Etkisinin İncelenmesi. Doktora Tezi. Gazi Üniversitesi Eğitim Bilimleri Enstitüsü, Ankara 2011.

Justice L. M., Chow S. M., Capellini C., Flanigan. K. \& Colton S. (2003). "Emergent Literacy Intervention for Vulnerable Preschoolers: Relative Effects of Two Approaches". American Journal of Speech-Language Pathology 12 (2003) 320 - 332. Doi: 10.1044/1058-0360(2003/078)

Justice L. M., McGinty A. S., Cabell S. Q., Kilday C. R., Knighton K. \& Huffman G. (2010). "Language and Literacy Curriculum Supplement for Preschoolers who are Academically at Risk: A Feasibility Study". Language, Speech, and Hearing Services in School 41/2 (2010) 161-178. Doi: 10.1044/01611461(2009/08-0058).

Kail R. V. $\left(2010^{5}\right)$. Children and Their Development. Boston 2010.

Kandır A., Özbey S. \& İnal G. (2010). Okul Öncesi Eğitimde Program (1) Kuramsal Temeller. İstanbul 2010.

Kandır A., Can-Yaşar M., İnal G., Yazıcı E., Ceylan Ş., Yazııı Z., Çalışandemir F., Özbey S. \& Uyanık Ö. (2012). Dil Etkinlikleri. Ankara 2012.

Kaptan S. (1998). Bilimsel Araştırma ve İstatistik Teknikleri. Ankara 1998.

Kaufman A. S. \& Kaufman N. L. (1993). K-SEALS Kaufman Survey of Early Academic and Language Skills: Manual. Minneapolis 1993.

Kaymak S. (1995). Yuvaya Giden Beş Yaşındaki Çocuklarla Dikkat Toplama Çalışmaları. Yüksek Lisans Tezi. Ankara Üniversitesi, Sosyal Bilimler Enstitüsü, Ankara 1995.

Kesicioğlu O. S. (2011). Doğrudan Öğretim Yöntemiyle Hazırlanan Eğitim Programının ve Bu Yönteme Göre Hazırlanan Bilgisayar Destekli Eğitim Programının Okul Öncesi Çocuklarının Geometrik Şekil Kavramlarını Öğrenmelerine Etkisinin İncelenmesi. Yayımlanmamış Doktora Tezi. Gazi Üniversitesi, Eğitim Bilimleri Enstitüsü, Ankara 2011.

Kidd J. K., Pasnak R., Gadzichowski M., Ferral-Like M. \& Gallington D. (2008). "Enhancing Early Numeracy by Promoting the Abstract Thought Involved in the Oddity Princible, Seriation and Conversation. Journal of Advanced Academics 19/2 (2008) 164-200.

Klauer J. K. \& Phye D. G. (2008). "Inductive Reasoning: A Training Approach”. Review of Educational 
Research 78/1 (2008) 85-123. Doi: 10.3102/0034654307313402

Klein P. S., Adi-Japha E. \& Hakak-Benizri S. (2010). "Mathematical Thinking of Kindergarten Boys and Girls: Similar Achievement, Different Contributing Processes". Educational Studies in Mathematics 73/3 (2010) 233-246. Doi: 10.1007/s10649-009-9216-y

Koç E. (2002). Görsel Algı Becerilerinin Gelişimine Yönelik Örnek Bir Program Modelinin Hazırlanması ve Anasınıfi Çocuklarında Görsel Algl Gelişimine Etkisinin Incelenmesi. Yayımlanmamış Yüksek Lisans Tezi. Gazi Üniversitesi, Eğitim Bilimleri Enstitüsü, Ankara 2002.

Kurtuluş K. (2010). Araştırma Yöntemleri. İstanbul 2010.

Lee K., Anzures G. \& Freire A. (2011). “ Cognitive Development in Adolescence”. Eds. A. Slater \& G. Bremner, An Introduction to Developmental Psychology (2011) 517-550. Great Britain 2011.

Mclachlan C., Fleer M. \& Edwards S. $\left(2013^{2}\right)$. Early Childhood Curriculum, Planning, Assessment and Implementation. New York 2013.

Milli Eğitim Bakanlığg (2006). 36-72 Aylık Çocuklar İçin Okul Öncesi Eğitim Programı. Ankara 2006.

Milli Eğitim Bakanlığı (2013). Okul Öncesi Eğitim Programı. Ankara 2013.

Morrow M. L. \& Gambrell B. L. (2004). Using Children's Literature in Preschool Comprehending and Enjoying Books. Newark 2004.

Munro J. (1998). "Phonological and Phonemic Awareness: Their Impact on Learning to Read Prose and to Spell”. Australian Journal of Learning Disabilities 3/2 (1998) 15-21.

Doi: 10.1080/19404159809546559

Murphy M. M. (2007). Enhancing Print Knowledge, Phonological Awareness, and Oral Language Skills With At-Risk Preschool Children in Head Start Classrooms. Doctoral Dissertation. University of Nebraska, Lincoln 2007. Retrieved from http://digitalcommons.unl.edu/dissertations/AAI3271904/

Nadal M., Amengual-Bunyola G. A., Ramis C., Capó M. \& Cela-Conde C. J. (2006). "Recent Genetic Contributions to the Study of Language". Ludus Vitalis 14 (2006) 187-204.

Neuman S. B. \& Dickinson D. K. (2002). Handbook of Early Literacy Development. New York 2002.

Oakley L. (2004). Cognitive Development. London 2004.

Ornstein A. C. \& Hunkins F. P. (2014). Curriculum Foundations, Principles, and Issues. Edinburg 2014.

Özyürek A. \& Ömeroğlu E. (2013). "Bellek Eğitimi Programının Altı Yaşındaki Çocukların Bellek Gelişimine Etkisinin İncelenmesi”. Ĕgitim ve Bilim 38/168 (2013) 30-45.

Patton M. Q. $\left(2002^{3}\right)$. Qualitative Research \& Evaluation Methods. California 2002.

Poe D. M., Burchinal R. M. \& Roberts E. J. (2004). "Early Language and the development of Children's Reading Skills". Journal of School Psychology 42/4 (2004) 315-332. Doi: 10.1016/j.jsp.2004.06.001

Reed M. A. (2009). Children and Language: Development, Impairment, and Training. New York 2009.

Riley J. (2006). Language and Literacy 3-7, Creative Approaches to Teaching. London 2006.

Sarıtaş R. (2010). Milli Ĕgitim Bakanlı̆̆ Okul Öncesi Ĕ̆itim Programına Uyarlanmış GEMS (Great Explorations in Math and Science) Fen ve Matematik Programının Anaokuluna Devam Eden Altı Yaş Grubu Çocukların Kavram Edinimleri ve Okula Hazır Bulunuşluk Düzeyleri Üzerindeki Etkisinin Incelenmesi. Yayımlanmamış Doktora Tezi. Gazi Üniversitesi, Eğitim Bilimleri Enstitüsü, Ankara 2010.

Sophian C. (2004). "Mathematics for the Future: Developing a Head Start Curriculum to support Mathematics Learning”. Early Childhood Research Quarterly 19/1 (2004) 59-81. Doi:_10.1016/j.ecresq.2004.01.015

Sönmez A. \& Alacapınar G. F. (2013²). Örneklendirilmiş Bilimsel Araştırma Yöntemleri. Ankara 2013.

Starkey P., Klein A. \& Wakeley A. (2004). "Enhancing Young Children's Mathematical Knowledge Through a Pre-Kindergarten Mathematics Intervention". Early Childhood Research Quarterly 19/1 (2004) 99-120. Doi: 10.1016/j.ecresq.2004.01.002

Strickland D. S. \& Riley-Ayers S. (2007). Literacyleadership in Early Childhood. New York 2007.

Şimşek Ö. (2007). Anasınıfına Devam Eden Çocukların Okuma Olgunluğu Düzeyine Türkçe Dil Etkinlik Programının Etkisinin İncelenmesi. Yayımlanmamış Yüksek Lisans Tezi. Gazi Üniversitesi, Eğitim Bilimleri Enstitüsü, Ankara 2007. 
Şimşek Ö. (2011). 60-72 Aylık Çocukların Yazı Farkındalı̆̆ı ve Yazmaya Hazırlık Becerilerinin Gelişiminde Okuma Yazmaya Hazırlık Programının Etkisinin Incelenmesi. Yayımlanmamış Doktora Tezi. Gazi Üniversitesi, Eğitim Bilimleri Enstitüsü, Ankara 2011.

Tomic W. \& Klauer J. K. (1996). "On the Effects of Training Inductive Reasoning How Far Does it Transfer and How Long to Be Effects Persist?”. European Journal of Psychology of Education XI/3 (1996) 283-299. Doi: 10.1007/BF03172941

Topbaş S. (2005). “Konuşma Dilinin Evrim Sürecinde İletişim-Dil-Konuşma Bağıntısı”. Ed. S. Topbaş, Dil ve Kavram Gelişimi (2005) 7-21. Ankara 2005.

Turhan G. (2004). Anasınıfina Devam Eden Alt Sosyo-Ekonomik Düzeydeki Çocuklara Uygulanan Matematiksel Kavramları Destekleyici Eğitim Programının Cümle ve Sayı Olgunluğuna Etkisinin Incelenmesi. Yüksek Lisans Tezi. Gazi Üniversitesi, Eğitim Bilimleri Enstitüsü, Ankara 2004.

Türkmenoğlu F. (2005). 60-72 Aylık Çocukların Matematik Becerilerini Kazanmalarında Oyun Yoluyla Matematik Becerilerini Kazandırma Programının Etkisinin Incelenmesi. Yüksek Lisans Tezi. Gazi Üniversitesi, Eğitim Bilimleri Enstitüsü, Ankara 2005.

Uyanık Ö. \& Kandır A. (2014). “Kaufman Erken Akademik ve Dil Becerileri Araştırma Testi’nin 61-72 Aylık Türk Çocuklarına Uyarlanması”. Kuram ve Uygulamada Eğitim Bilimleri 14/2 (2014) 669-692. Doi: 10.12738/estp.2014.2.1682.

Ünal F. (2007). “Anasınıfına Devam Eden Çocukların Kısa Süreli Bellek Gelişimine Bellek Eğitiminin Etkisinin İncelenmesi”. Mesleki Ĕgitim Dergisi 9/18 (2007) 253-267.

van der Sluis S., de Jong B. F. \& van der Leij A. (2007). "Executive Functioning in Children, and its Relations With Reasoning, Reading, and Arithmetic”. Intelligence 35 (2007) 427- 449.

Doi: 10.1016/j.intell.2006.09.001

Wood E. (2013). Play Learning and the Early Childhood Curriculum. London 2013.

White S. C. \& Manning B. H. (1994). "The Effects of Verbal Scaffolding Instruction on Young Children's Private Speech and Problem-Solving Capabilities”. Instructional Science 22 (1994) 39-59. Doi: 10.1007/BF00889522

Welsh J. A., Nix R. L., Blair C., Bierman K. L. \& Nelson K. E. (2010). "The Development of Cognitive Skills and Gains in Academic School Readiness for Children from Low-Income Families". Journal of Educational Psychology 102/1 (2010) 43-53. Doi: 10.1037/a0016738

Yayla Ş. (2003). Alt Sosyo-Ekonomik Düzeydeki Ailelerden Gelen 60-72 Aylar Arasındaki Çocuklara Uygulanan Dil Eğitim Programının Çocukların Dil Gelişimine Etkisinin İncelenmesi. Yayımlanmamış Yüksek Lisans Tezi. Gazi Üniversitesi Eğitim Bilimleri Enstitüsü, Ankara 2003.

Yazıcı G. Z. (2007). Birinci ve İkinci Dili Türkçe Olan İki Dilli Çocukların Türkçe’yi Kazanımlarına Dil Merkezli Okul Öncesi Eğitim Programının Etkisi. Yayımlanmamış Doktora Tezi. Gazi Üniversitesi Eğitim Bilimleri Enstitüsü, Ankara 2007.

Yazıcı E. \& Kandır A. (2014). “Okuma Yazma Becerilerini Destekleyici Duyu Eğitimi Programının 6166 Aylık Çocukların Okuma Yazma Becerilerine Etkisi”. Uluslararası Sosyal Araştırmalar Dergisi 7/33 (2014) 686-701.

Yazzie A. (2009). Visual-Spatial Thinking and Academic Achievement: A Concurrent and Predictive Validity Study. Doctoral Dissertation. Northern Arizona University, Arizona 2009. Retrieved from http://gradworks.umi.com/33/70/3370650.html

Yıldırım A. \& Şimşek H. (2005). Sosyal Bilimlerde Nitel Araştırma Yöntemleri. Ankara 2005.

Young-Loveridge J. M. (2004). "Effects on Early Numeracy of a Program Using Number Books and Games”. Early Childhood Research Quarterly 19/1 (2004) 82-98. Doi: 10.1016/j.ecresq.2004.01.001 